\title{
Chasing cardiac physiology and pathology down the CaMKII cascade
}

\author{
Alicia Mattiazzi, ${ }^{1}$ Rosana A. Bassani, ${ }^{2}$ Ariel L. Escobar, ${ }^{3}$ Julieta Palomeque, ${ }^{1}$ Carlos A. Valverde, ${ }^{1}$ \\ Martín Vila Petroff, ${ }^{1}$ and Donald M. Bers ${ }^{4}$ \\ ${ }^{1}$ Centro de Investigaciones Cardiovasculares, The National Scientific and Technical Research Council-La Plata, Facultad de \\ Ciencias Médicas, Universidad Nacional de La Plata, La Plata, Argentina; ${ }^{2}$ Centro de Engenharia Biomédica, Universidade \\ Estadual de Campinas, Campinas, SP, Brazil; ${ }^{3}$ Biological Engineering and Small Scale Technologies, School of Engineering, \\ University of California, Merced, California; and ${ }^{4}$ Department of Pharmacology, University of California Davis, Davis, \\ California
}

Submitted 7 January 2015; accepted in final form 16 February 2015

\begin{abstract}
Mattiazzi A, Bassani RA, Escobar AL, Palomeque J, Valverde CA, Vila Petroff M, Bers DM. Chasing cardiac physiology and pathology down the CaMKII cascade. Am J Physiol Heart Circ Physiol 308: H1177-H1191, 2015. First published March 4, 2015; doi:10.1152/ajpheart.00007.2015.—Calcium dynamics is central in cardiac physiology, as the key event leading to the excitation-contraction coupling (ECC) and relaxation processes. The primary function of $\mathrm{Ca}^{2+}$ in the heart is the control of mechanical activity developed by the myofibril contractile apparatus. This key role of $\mathrm{Ca}^{2+}$ signaling explains the subtle and critical control of important events of ECC and relaxation, such as $\mathrm{Ca}^{2+}$ influx and $\mathrm{SR} \mathrm{Ca}^{2+}$ release and uptake. The multifunctional $\mathrm{Ca}^{2+}$-calmodulin-dependent protein kinase II (CaMKII) is a signaling molecule that regulates a diverse array of proteins involved not only in ECC and relaxation but also in cell death, transcriptional activation of hypertrophy, inflammation, and arrhythmias. CaMKII activity is triggered by an increase in intracellular $\mathrm{Ca}^{2+}$ levels. This activity can be sustained, creating molecular memory after the decline in $\mathrm{Ca}^{2+}$ concentration, by autophosphorylation of the enzyme, as well as by oxidation, glycosylation, and nitrosylation at different sites of the regulatory domain of the kinase. CaMKII activity is enhanced in several cardiac diseases, altering the signaling pathways by which CaMKII regulates the different fundamental proteins involved in functional and transcriptional cardiac processes. Dysregulation of these pathways constitutes a central mechanism of various cardiac disease phenomena, like apoptosis and necrosis during ischemia/reperfusion injury, digitalis exposure, post-acidosis and heart failure arrhythmias, or cardiac hypertrophy. Here we summarize significant aspects of the molecular physiology of CaMKII and provide a conceptual framework for understanding the role of the CaMKII cascade on $\mathrm{Ca}^{2+}$ regulation and dysregulation in cardiac health and disease.
\end{abstract}

$\mathrm{Ca}^{2+}$; CaMKII; ischemia/reperfusion; cell death; arrhythmias; hypertrophy

THIS ARTICle is part of a collection on 1st PanAmerican Congress of Physiological Sciences: Physiology Without Borders. Other articles appearing in this collection, as well as a full archive of all collections, can be found online at http:// ajpheart.physiology.org/.

Calcium signaling is central in cardiac physiology and the link of the different steps of excitation-contraction coupling (ECC) and relaxation mechanisms. Moreover, the multifunctional $\mathrm{Ca}^{2+}$-calmodulin-dependent protein kinase II (CaMKII) is a signaling molecule that regulates ECC in the heart but is also involved in several cardiac diseases. The present review proffers an outline of intracellular $\mathrm{Ca}^{2+}$ handling in the heart, as well as on CaMKII localization, regulation, and targets in the cardiac myocyte. The review also focuses on $\mathrm{Ca}^{2+}$ dys-

Address for reprint requests and other correspondence: A. Mattiazzi, Centro de Investigaciones Cardiovasculares, Facultad de Ciencias Médicas, 60 y 120, 1900, La Plata, Argentina (e-mail: ramattia@med.unlp. edu.ar). regulation and CaMKII activation in ischemia/reperfusion (I/ $\mathrm{R}$ ), as well as the dual role of CaMKII in this condition (i.e., beneficial in the stunned heart, but detrimental in irreversible I/R injury, leading to apoptosis and necrosis). We also address the importance of ryanodine receptors (RyR2) and their regulation by CaMKII in different proarrhythmic processes, such as those occurring during reperfusion, after acidosis, atrial fibrillation, heart failure (HF), and digitalis intoxication. Finally, the role of CaMKII in cardiac transcriptional regulation is described. We hope that this review may help to provide a solid basis for understanding the importance of the CaMKII cascade in cardiac health and disease.

\section{Overview of Intracellular $\mathrm{Ca}^{2+}$ Dynamics}

Calcium is a remarkably ubiquitous and versatile intracellular signal, since not only does it trigger and regulate a number of physiological processes but also may play an important role in regulation of its own fluxes among cell organelle and plasma membranes. The primary function attributed to $\mathrm{Ca}^{2+}$ in muscle 
cells is to control mechanical activity developed by the myofibril contractile apparatus. In the cardiac muscle, membrane depolarization during the action potential (AP) triggers a transient rise in cytosolic free $\mathrm{Ca}^{2+}$ concentration $\left(\left[\mathrm{Ca}^{2+}\right]_{\mathrm{i}}\right)$ that leads to a phasic contraction. Thus $\mathrm{Ca}^{2+}$ dynamics in the cytosol is the most critical event in the ECC process.

In the mature mammalian ventricular myocardium, most of the $\mathrm{Ca}^{2+}$ that contributes to an AP-triggered $\mathrm{Ca}^{2+}$ transient is released from the sarcoplasmic reticulum (SR) (27), upon binding of $\mathrm{Ca}^{2+}$ to RyR2 (Fig. 1), a mechanism identified as $\mathrm{Ca}^{2+}$-induced $\mathrm{Ca}^{2+}$ release (38). These channels are homotetramers and are assembled in a macromolecular complex that includes RyR2 regulatory molecules, such as calmodulin (CaM), FK-506 binding proteins (FKBP12/12.6), and protein phosphatases and kinases, including CaMKII $(64,135,144)$. Thus $\mathrm{Ca}^{2+}$ can regulate the channels by both, direct binding to them and via $\mathrm{CaM}$ and CaMKII. During the $\mathrm{AP}, \mathrm{Ca}^{2+}$ influx through voltage-dependent L-type $\mathrm{Ca}^{2+}$ channels (LTCC) causes a rapid and large increase in subsarcolemmal $\left[\mathrm{Ca}^{2+}\right]$, which results in the synchronized opening of RyR2 clusters and massive $\mathrm{Ca}^{2+}$ release to the dyadic space, from which $\mathrm{Ca}^{2+}$ diffuses to the bulk cytosol and reaches the myofilaments (Fig. 1). It is accepted that $\mathrm{SR} \mathrm{Ca}^{2+}$ release during ECC is terminated by closure of the RyR2, attributed to regulation of the channels by intra-SR local free $\left[\mathrm{Ca}^{2+}\right]$ and proteins directly or indirectly associated with RyR2, such as calsequestrin, triadin, and junctin $(47,59,158)$. Because the release is not sustained, the cytosolic $\mathrm{Ca}^{2+}$ transient is self-limiting, since the rise in $\left[\mathrm{Ca}^{2+}\right]_{i}$ not only activates contraction but also increases the transport rate of mechanisms that remove $\mathrm{Ca}^{2+}$ from the cytosol, thus causing $\left[\mathrm{Ca}^{2+}\right]_{\mathrm{i}}$ to fall and mechanical relaxation to occur. Among these transporters, the most prominent is the SR $\mathrm{Ca}^{2+}$-ATPase (SERCA2a), located in the extra-dyadic SR, which allows refilling the $\mathrm{SR} \mathrm{Ca}^{2+}$ store $(8$, 89). SERCA2a is negatively regulated by phospholamban (PLN; Fig. 1). However, this inhibition may be relieved by
PLN phosphorylation, which decreases the PLN-SERCA interaction $(29,61)$. Moreover, the effects of PLN on cardiac function are subjected to additional regulation by its interacting partners (61). The most important $\mathrm{Ca}^{2+}$ efflux mechanism is the $\mathrm{Na}^{+}-\mathrm{Ca}^{2+}$ exchanger (NCX), which, at steady-state cyclic activity, removes most of the $\mathrm{Ca}^{2+}$ that enters the cell during the AP $(27,33)$, whereas slower mechanisms (the sarcolemmal $\mathrm{Ca}^{2+}$-ATPase and mitochondrial $\mathrm{Ca}^{2+}$ influx pathways) do not seem to play a significant role in the decline of electrically triggered $\mathrm{Ca}^{2+}$ transients in the mature myocardium $(7,19)$.

Because the SR is the major $\mathrm{Ca}^{2+}$ source for ECC, it is plausible to consider that contraction amplitude largely depends on how much $\mathrm{Ca}^{2+}$ is released from it. During a twitch, this organelle releases only a fraction $(50-70 \%)$ of its total content $(6,10,117,118)$. Several factors seem to determine the fractional SR $\mathrm{Ca}^{2+}$ release: 1) the amplitude of the release trigger, i.e., typically L-type $\mathrm{Ca}^{2+}$ current $\left.\left(I_{\mathrm{CaL}}\right)(6) ; 2\right)$ the SR $\mathrm{Ca}^{2+}$ content, especially the free $\left[\mathrm{Ca}^{2+}\right]$ in the SR lumen $(6$, 117), since evidence indicates that the RyR2 activity is regulated not only by cytosolic but also by intra-SR $\mathrm{Ca}^{2+}(26,47$, $60,65)$; and 3) the RyR2 functional state, which can be altered by interaction with proteins (e.g., FKBP12.6, CaM, luminal proteins), divalent cations, ATP and other compounds, by phosphorylation, and by post-translational modifications by reactive oxygen species (ROS) and reactive nitrogen species $(30,47,64,91,144)$.

The SR $\mathrm{Ca}^{2+}$ content available for release during ECC basically depends on the balance between uptake and release rates during the decline of the $\mathrm{Ca}^{2+}$ transient and diastole. The rate of diastolic SR $\mathrm{Ca}^{2+}$ release ( $\mathrm{SR} \mathrm{Ca}^{2+}$ leak) is low in myocardial cells $(9,14,74,157)$. Diastolic SR $\mathrm{Ca}^{2+}$ leak may be augmented by an increase in SR $\mathrm{Ca}^{2+}$ load and by other factors that increase the RyR2 activity state, e.g., phosphorylation (14).

$\mathrm{SR} \mathrm{Ca}^{2+}$ release is not only involved in determining cardiac contractility, but it also can modify the sarcolemmal electrical
Fig. 1. $\mathrm{Ca}^{2+}$ fluxes associated with excitation-contraction coupling in mammalian cardiac myocytes. During the action potential, $\mathrm{Ca}^{2+}$ influx via L-type $\mathrm{Ca}^{2+}$ channels (LTCC) triggers $\mathrm{Ca}^{2+}$ release from the sarcoplasmic reticulum (SR) by $\mathrm{Ca}^{2+}$ binding to the ryanodine receptors (RyR2) in the SR membrane. In addition to interacting with the myofilaments (MF), $\mathrm{Ca}^{2+}$ is removed from the cytosol mainly by the SR $\mathrm{Ca}^{2+}$-ATPase (SERCA2a), which is regulated by phospholamban (PLN), and by the electrogenic sarcolemmal $\mathrm{Na}^{+} / \mathrm{Ca}^{2+}$ exchanger (NCX1), which is driven by the $\mathrm{Na}^{+}$electrochemical gradient across the membrane. This gradient is maintained by the $\mathrm{Na}^{+}-\mathrm{K}^{+}$-ATPase (NKA). Intracellular $\left[\mathrm{Na}^{+}\right]$may also be affected by the operation of the $\mathrm{Na}^{+}-\mathrm{H}^{+}$exchanger (NHE).

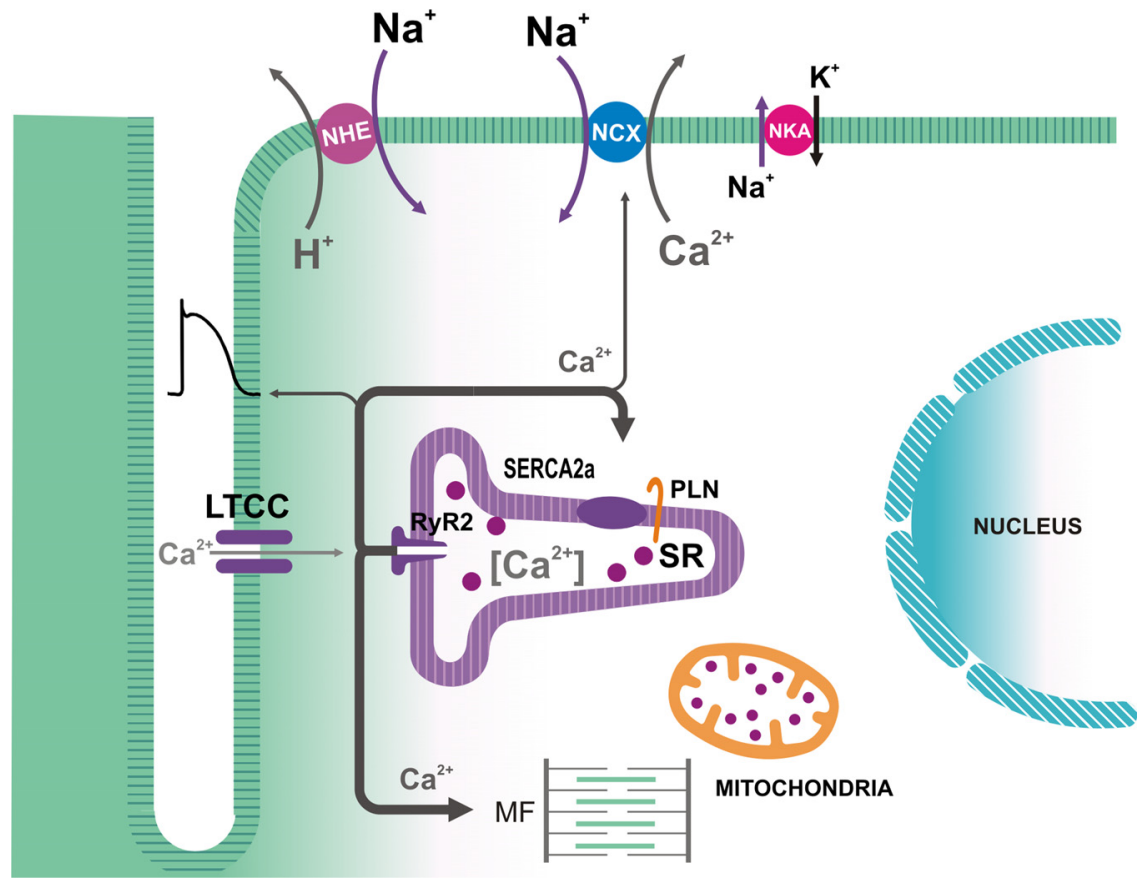


properties, affecting the AP shape. One obvious mechanism involves $\mathrm{Ca}^{2+}$-dependent inactivation of the $\operatorname{LTCC}(37,124)$ : a large $\mathrm{Ca}^{2+}$ release will reduce sarcolemmal $\mathrm{Ca}^{2+}$ influx, shortening the AP. However, mechanisms involved in activation of $\mathrm{Cl}^{-}(66)$ and/or $\mathrm{K}^{+}(68,131)$ channels by $\mathrm{Ca}^{2+}$ have also been postulated to modify the AP repolarization phase. Schouten and ter Keurs (115) first showed that the late and relatively negative AP plateau seen in rat ventricular myocytes is driven by $\mathrm{Ca}^{2+}$-dependent inward NCX current. Shattock and Bers (119) detected NCX-dependent $\mathrm{Ca}^{2+}$ extrusion by measuring transient interstitial $\left[\mathrm{Ca}^{2+}\right]_{\mathrm{o}}$ elevation during the $\left[\mathrm{Ca}^{2+}\right]_{\mathrm{i}}$ transient. More recently, Ferreiro et al. (39) demonstrated that in the intact mouse heart under physiological conditions, $\mathrm{Ca}^{2+}$ release from the SR can cause an AP phase 2 that is more positive than that traditionally reported in rat or mouse ventricular myocytes, but that is still mediated by inward NCX current that is driven by SR $\mathrm{Ca}^{2+}$ release. Moreover, this more prominent AP plateau in mouse ventricle resembles that observed in both human atrial myocytes and the ventricular epicardium of other mammals (i.e., dog, cat, pig, etc.).

\section{CaMKII Structure, Function, and Targets}

Molecular physiology and localization. CaMKII is a multimeric holoenzyme complex consisting of a pair of hexameric assembled rings (Fig. 2A). There are four CaMKII gene products: $\alpha, \beta, \gamma, \delta$ (52). These genes show differential tissue expression, with CaMKIII being the predominant isoform in the heart (32), although CaMKII $\gamma$ is also present (120). In the adult myocardium, two major splice variants of CaMKII $\delta$ are expressed: $\mathrm{CaMKIII}_{\mathrm{B}}$ and $\mathrm{CaMKIII}_{\mathrm{C}}$ (32). CaMKIII $\delta_{\mathrm{B}}$ possesses an 11-amino acid nuclear localization signal that is responsible for its preferential nuclear localization, whereas the splice variant $\delta_{C}$ (lacking only this 11-amino acid nuclear localization signal) is preferentially localized in the cytosol (122). It is also well known that most CaMKII isoforms readily form stable hetero-oligomers, such that the ratio of $\delta_{B}$ to $\delta_{C}$ in a multimer could regulate the localization of the holoenzyme $(100,122)$. However, even when only one splice variant $\left(\mathrm{CaMKII}_{\mathrm{B}}\right.$ or $\left.\mathrm{CaMKII} \delta_{\mathrm{C}}\right)$ is expressed, CaMKII $\delta_{\mathrm{B}}$ is not exclusively nuclear and CaMKIII $\delta_{\mathrm{C}}$ is not exclusively cytosolic. Interestingly, the relative expression of CaMKIII $\delta_{B}$ can be altered in vitro by phosphorylation/dephosphorylation processes and has been shown to be modified under different physiological and pathological conditions, suggesting that CaMKII $\delta$ splicing is a highly regulated dynamic process (44). Indeed, recent experimental evidence suggests that CaMKII $\delta$ splice variants are selectively susceptible to autophosphorylation/oxidation, providing CaMKII with a mechanism for target signaling specificity (12).

Mechanisms of CaMKII activation and regulation. As shown in Fig. $2 A$, each CaMKII monomer that composes the holoenzyme consists of three domains: an $\mathrm{NH}_{2}$-terminus catalytic domain, a COOH-terminus association domain, and a core regulatory domain. Under basal conditions, the catalytic domain is restrained by the pseudo substrate region within the regulatory domain, which hampers the CaMKII catalytic activity. The regulatory domain binds $\mathrm{CaM}$ with a $\mathrm{K}_{\mathrm{D}}$ of $10-70$ $\mathrm{nM}$ (41), when intracellular $\mathrm{Ca}^{2+}$ concentration is elevated (102). CaM binding to CaMKII generates a conformational shift that releases the association between the catalytic and regulatory domains, exposing the catalytic domain for substrate binding and phosphorylation. If a sustained increase in $\mathrm{Ca}^{2+} / \mathrm{CaM}$ interaction occurs, the already active CaMKII monomers catalyze the autophosphorylation of the kinase at $\mathrm{Thr}^{286}$ (or $\mathrm{Thr}^{287}$, depending on isoform). CaMKII phosphorylation increases the binding affinity of the enzyme for $\mathrm{Ca}^{2+}$ / $\mathrm{CaM}$ (79), preventing the re-association of the catalytic and regulatory domains (63) and retaining residual $\mathrm{Ca}^{2+} / \mathrm{CaM}-$ independent or autonomous activity (52). CaMKII $\delta$ can be also oxidized at MetMet ${ }^{281 / 282}\left(\mathrm{CysMet}^{280 / 281}\right.$ in CaMKII $\left.\alpha\right)$, which induces a similar $\mathrm{Ca}^{2+} / \mathrm{CaM}$-independent form of CaMKII (35). Interestingly, oxidation of CaMKII resets its $\mathrm{Ca}^{2+}$ sensitivity in such a way that activation of the kinase may occur at very low levels of intracellular $\mathrm{Ca}^{2+}$ (93). Indeed, activation of the renin-angiotensin-aldosterone signaling pathway, which promotes enhanced oxidative stress in the heart (87), induces CaMKII-dependent apoptosis of cardiac myocytes in the absence of significant increases in cytosolic $\mathrm{Ca}^{2+}$ in vitro (93) and in vivo (136). Moreover, apoptosis induced by the hormone is prevented in isolated neonatal mouse myocytes expressing the oxidation-resistant mutant CaMKII (35). Similarly, in the prediabetic stage induced in a model of impaired glucose tolerance, it has been described that the increase in oxidative stress contributed to CaMKII activation, SR $\mathrm{Ca}^{2+}$ leak, and the generation of arrhythmias and apoptosis (94, 121). These findings suggest that conditions of high ROS production may lead to increased CaMKII activity, even in the absence of changes in the basal levels of $\mathrm{Ca}^{2+} / \mathrm{CaM}$. Interestingly, recent experiments have described that ROS production may also occur downstream CaMKII activation $(92,116)$. These experiments suggest that under conditions of high oxidative stress, a vicious cycle of CaMKII activation and ROS production may occur. Further experimental evidence is required to confirm this possibility.

Two additional posttranslational modifications of CaMKII have been recently reported. Erickson et al. (36) described, using overt diabetes cellular and animal models, a novel mechanism for CaMKII activation during hyperglycemia, different from that produced by the oxidation of CaMKII, typical of diabetic patients (71). This mechanism occurs through the addition of an O-linked $\mathrm{N}$-acetylglucosamine (O-GlcNAc) at the $\operatorname{Ser}^{280}$ site, which similarly to oxidation and phosphorylation, creates molecular memory after the decline in $\mathrm{Ca}^{2+}$ concentration. It has also been shown that nitric oxide production by $\beta$-adrenergic stimulation is sufficient, by itself, to activate CaMKII and increase SR $\mathrm{Ca}^{2+}$ leak, leading to arrhythmogenic spontaneous $\mathrm{Ca}^{2+}$ waves $(22,46,56)$. Zhang et al. (153) further showed that nitric oxide-PKG signaling augmented CaMKII activity in rabbit ventricular myocytes. Moreover, in vitro studies showed that CaMKII contains $S$-nitrosylated cysteine residues, and computational prediction of $S$ nitrosylation sites on CaMKII indicates different potential target sites, including the $\mathrm{Cys}^{290}$ site in the CaMKII $\delta$ regulatory domain (46). Coultrap and Bayer (21) recently demonstrated that nitrosylation of CaMKII $\alpha$ at the analogous Cys ${ }^{289}$ and also $\mathrm{Cys}^{280}$ (Met ${ }^{281}$ in CaMKII $\delta$ ) sites was critical to autonomous CaMKII activation by nitric oxide donors. The cluster of the different regulatory sites at the regulatory/autoinhibitory CaMKII-domain suggests that these sites are part of a hotspot region for post-translational regulation of the kinase. 
Fig. 2. A: schematic representation of CaMKII structure and regulation. See text for description. Note the proximity of sites involved in the sustained regulation of CaMKII. The question mark in $\mathrm{Cys}^{290}$ indicates a computationally predicted site of CaMKII nitrosylation [modified from Erickson et al. (35)]. B: effects of $\mathrm{CaMKII}_{\mathrm{C}}$ on excitation-contraction coupling (ECC). See text for description. $I_{\mathrm{Na}}, \mathrm{Na}^{+}$current; $I_{\mathrm{to}}$, transient outward $\mathrm{K}^{+}$current; $I_{\mathrm{K} 1}$, inward rectifier $\mathrm{K}^{+}$current.
A

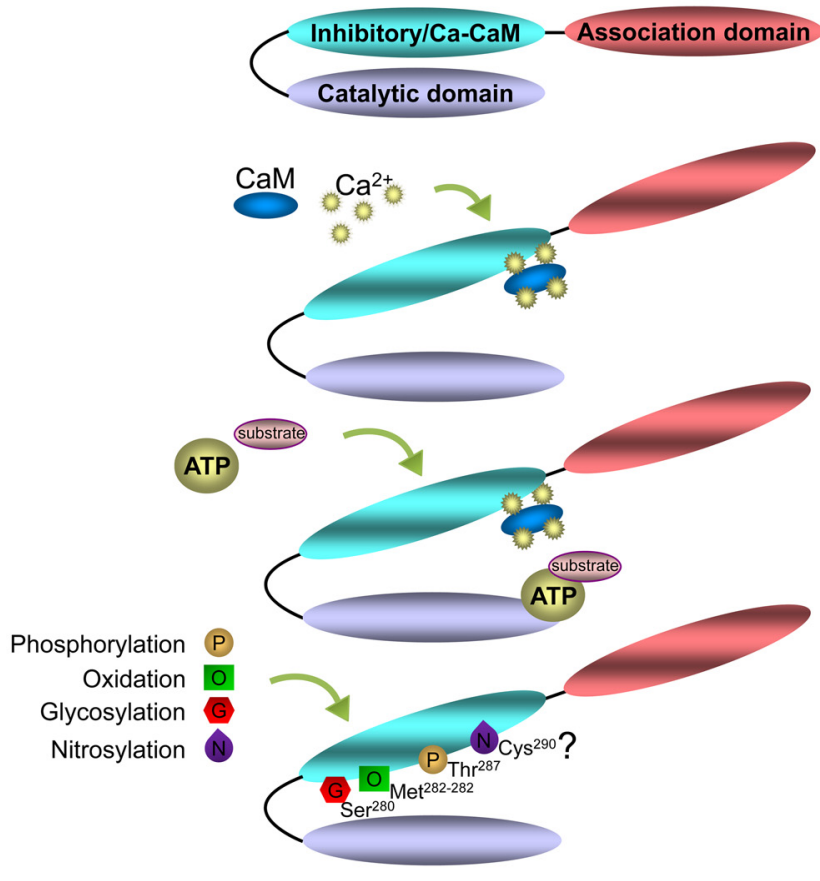

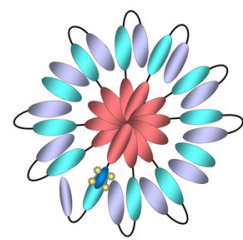

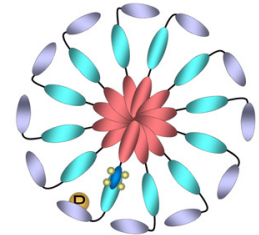

B

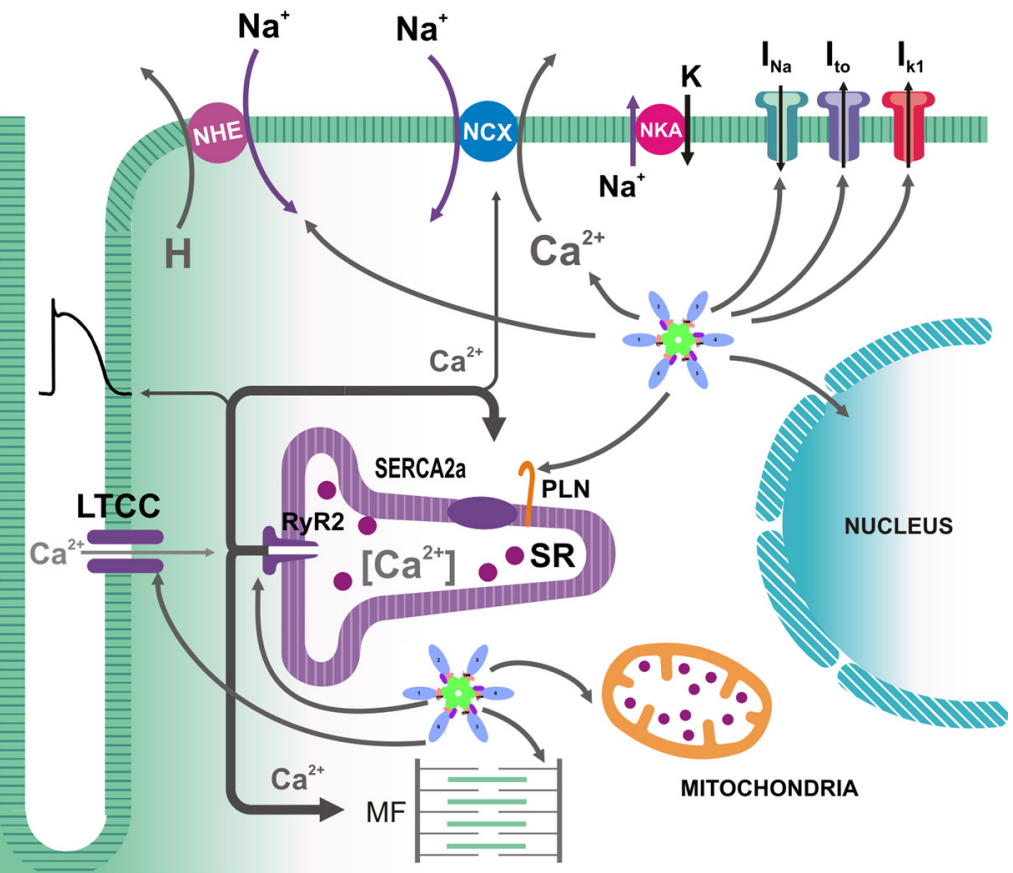

CaMKII targets in the heart. CaMKII regulates different ion channels and transport proteins involved in cardiac ECC (Fig. $2 B$ ). CaMKII-dependent phosphorylation of LTCC potentiates $I_{\mathrm{CaL}}$ and slows its inactivation (152). Experimental evidence indicates that, in the long term, both $\delta_{\mathrm{B}}$ and $\delta_{\mathrm{C}}$ CaMKII isoforms decrease the expression of LTCC pore-forming $\alpha 1 \mathrm{c}$ subunit (101). CaMKII-dependent phosphorylation of PLN increases SR $\mathrm{Ca}^{2+}$ uptake, whereas phosphorylation of RyR2 increases diastolic SR $\mathrm{Ca}^{2+}$ leak and systolic $\mathrm{SR} \mathrm{Ca}^{2+}$ release $(25,40,43,45,108,134,145)$. CaMKII also catalyzes phosphorylation of the $\mathrm{Na}^{+}-\mathrm{H}^{+}$exchanger (NHE-1) (139), and of the voltage-gated ion channels responsible for $\mathrm{Na}^{+}$current $\left(I_{\mathrm{Na}}\right)$, transient outward $\mathrm{K}^{+}$current $\left(I_{\mathrm{to}}\right)$, and inward rectifier $\mathrm{K}^{+}$current $\left(I_{\mathrm{K} 1}\right)(67,142,143)$. Persistent (late) inward $\mathrm{Na}^{+}$ current $\left(I_{\mathrm{NaL}}\right)$ is enhanced (gain-of-function effect). In contrast, $\mathrm{Na}^{+}$channel availability is reduced, intermediate inactivation 
is enhanced, and recovery from inactivation of rapid $I_{\mathrm{Na}}$ is slowed by CaMKII-dependent phosphorylation (loss-of-function effects) (142). The effects of CaMKII on $I_{\text {to }}$ and $I_{\mathrm{K} 1}$ are complex $(67,143)$. Acute and chronic CaMKII overexpression increases $I_{\text {to,slow }}$ amplitude and expression of the underlying channel protein $\mathrm{K}_{\mathrm{V} 1.4}$. On the other hand, chronic but not acute CaMKII overexpression causes downregulation of $I_{\text {to,fast }}$, as well as of $\mathrm{K}_{\mathrm{V} 4.2}$ and $\mathrm{KChIP} 2$. Interestingly, these amplitude changes were not reversed by acute CaMKII inhibition, consistent with CaMKII-dependent regulation of channel expression and/or trafficking (143).

It has also been shown that the overexpression of CaMKII $\delta_{\mathrm{B}}$ led to an increase in NCX abundance and disruption of the NCX/SERCA2 expression balance via class IIa histone deacetylase (HDACs)/myocyte enhancer factor-2 (MEF2)-dependent signaling (70). Moreover, available data indicates that NCX upregulation induced by $\beta$-adrenoceptor stimulation is dependent on CaMKII activation in the adult heart (72).

Further work demonstrated that CaMKII interacts with the mitochondrial $\mathrm{Ca}^{2+}$ uniporter (MCU) and promotes $\mathrm{Ca}^{2+}$ entry into the mitochondria, probably by catalyzing phosphorylation of serine residues 57 and 92 (57). Finally, two cardiac myofilament proteins are known to be phosphorylated by CaMKII. Cardiac myosin binding protein $\mathrm{C}$ can be phosphorylated at $\mathrm{Ser}^{282}$ and $\mathrm{Ser}^{302}$ [which are also protein kinase A (PKA) targets], although the functional effects of this phosphorylation remain to be resolved $(82,105)$. The spring region of the giant sarcomeric protein titin, a main determinant of diastolic stiffness, is also a target of CaMKII $\delta$. Interestingly, it has been shown that phosphorylation of this protein (possibly at the N2B element) increased during ischemia/reperfusion (49). As we further discuss next, it is now known that alterations in the phosphorylation of most of these proteins and transporters are crucially involved in the genesis of myocardial injury and arrhythmias.

$\mathrm{Ca}^{2+}$ and $\mathrm{CaMKII}$ in I/R

$\mathrm{Ca}^{2+}$ dysregulation in I/R. Ischemic heart disease, a leading cause of mortality worldwide, is invariably characterized by impaired cardiac function and disturbed $\mathrm{Ca}^{2+}$ homeostasis. Earlier experiments revealed an increase in diastolic $\left[\mathrm{Ca}^{2+}\right]_{i}$ during ischemia $(73,80,103,132)$. This increase has been related to a diversity of concurrently altered $\mathrm{Na}^{+}$-dependent $(55,85,99,128,129)$ and independent mechanisms $(88,123$, $125)$. The core of these changes essentially lies on the oxygen deprivation produced by blood flow reduction and the consequent shift from aerobic to anaerobic metabolism (86). Fluorescent detection of cytosolic and $\mathrm{SR} \mathrm{Ca}^{2+}$ transients at the epicardial layer of the intact beating heart (78) demonstrated

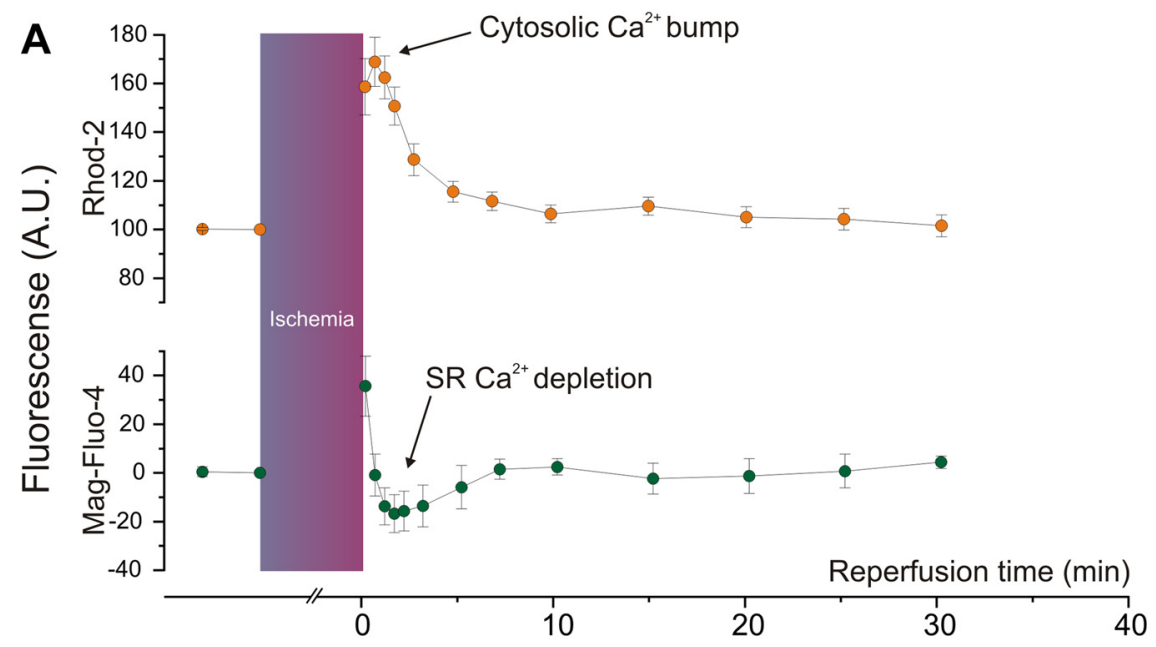

B

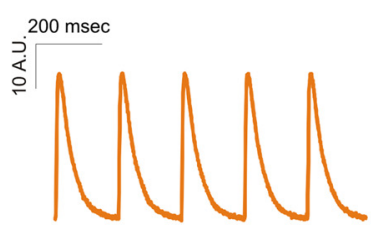

Preischemia

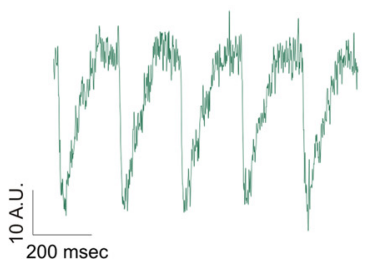

Fig. 3. A: increase in diastolic $\left[\mathrm{Ca}^{2+}\right]_{i}$ at the onset of reperfusion. At the onset of reperfusion, there is an abrupt increase in diastolic $\left[\mathrm{Ca}^{2+}\right]_{\mathrm{i}}\left(\mathrm{Ca}^{2+}\right.$ bump) associated with a mirror-like image of the decrease in SR $\mathrm{Ca}^{2+}$ content. Mean values are from individual signals recorded at the epicardial layer of intact hearts loaded with Rhod-2 and Mag-Fluo-4, respectively [modified from Valverde et al. (132)]. B: typical records showing the decrease in SR $\mathrm{Ca}^{2+}$ content associated with a diminished $\mathrm{Ca}^{2+}$ transient amplitude, after the $\mathrm{Ca}^{2+}$ bump. AU, arbitrary units. 
that the increase in cytosolic $\left[\mathrm{Ca}^{2+}\right]_{\mathrm{i}}$ during ischemia is associated with an enhancement of $\mathrm{SR} \mathrm{Ca}^{2+}$ load (132). The increased $\mathrm{SR} \mathrm{Ca}{ }^{2+}$ content was released at the onset of reperfusion, producing an abrupt rise in cytosolic $\left[\mathrm{Ca}^{2+}\right]_{\mathrm{i}}\left(\mathrm{Ca}^{2+}\right.$ bump) (Fig. 3A), and the subsequent decrease in $\mathrm{SR} \mathrm{Ca}^{2+}$ content was associated with a diminished $\mathrm{Ca}^{2+}$ transient amplitude (132) (Fig. 3B). More recent experiments further showed that a major mechanism for the increase in diastolic $\left[\mathrm{Ca}^{2+}\right]_{\mathrm{i}}$ during ischemia is an increase in the frequency of $\mathrm{Ca}^{2+}$ sparks. Notably, the increase in $\mathrm{Ca}^{2+}$ sparks during ischemia switched to an increase in arrhythmogenic $\mathrm{Ca}^{2+}$ waves during reperfusion (74) (Fig. 4).

Activation of CaMKII in I/R. Previous studies showed the time course of phosphorylation of $\mathrm{Thr}^{17}$ of PLN, used as a marker of CaMKII activation, during I/R. This initial work showed a significant increase in $\mathrm{Thr}^{17}$ phosphorylation at the beginning of ischemia and at the onset of reflow (141). Experimental evidence reveals that $\mathrm{Ca}^{2+}$ influx through LTCC and phosphatase inhibition, due to the ischemia-induced intracel- lular acidosis, play a central role in the activation of CaMKII at the beginning of ischemia $(83,84)$.

The increase in $\mathrm{Thr}^{17}$ phosphorylation at the onset of reperfusion may be produced by the transient increase in cytosolic $\left[\mathrm{Ca}^{2+}\right]$ that occurs at this time (86). This $\left[\mathrm{Ca}^{2+}\right]_{\mathrm{i}}$ increase has been usually attributed to the influx of $\mathrm{Ca}^{2+}$ through the reverse mode of the $\operatorname{NCX}(54,86,95)$. However, the abrupt $\mathrm{Ca}^{2+}$ release from the SR recently described at the onset of reperfusion (132) may also be greatly involved in the increase in CaMKII activation and PLN $\mathrm{Thr}^{17}$ phosphorylation at this moment.

Reperfusion is also associated with ROS generation (15). As described earlier in this review, both $\mathrm{Ca}^{2+}$ mishandling and ROS production set an ideal intracellular milieu for activation of CaMKII. Further studies have shown that other CaMKII substrates are also phosphorylated at the beginning of reperfusion, e.g., the $\mathrm{Ser}^{2814}$ site of RyR2, which have been shown to play a significant role in reperfusion injury $(28,108)$, as it will be discussed next.
A Preischemia

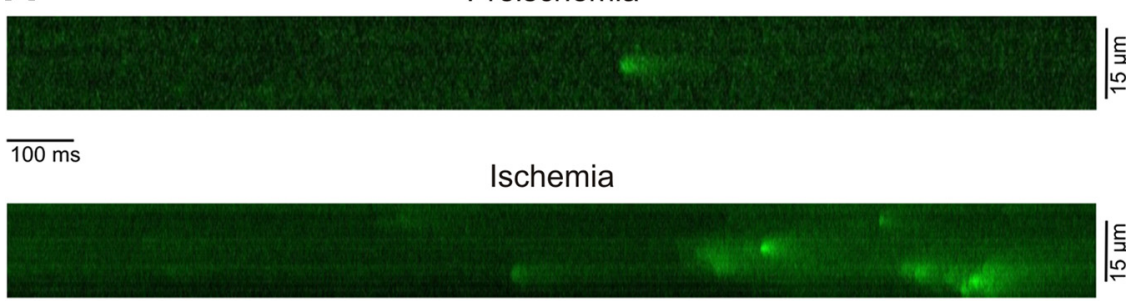

$\overline{100} \mathrm{~ms}$

Reperfusion

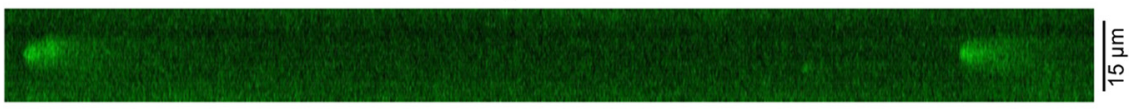

$\overline{100 \mathrm{~ms}}$

B

Fig. 4. $A-C: \mathrm{Ca}^{2+}$ sparks increase during ischemia and turn into $\mathrm{Ca}^{2+}$ waves during reperfusion. Typical examples and overall results are shown [modified from Mattiazzi et al. (74)].
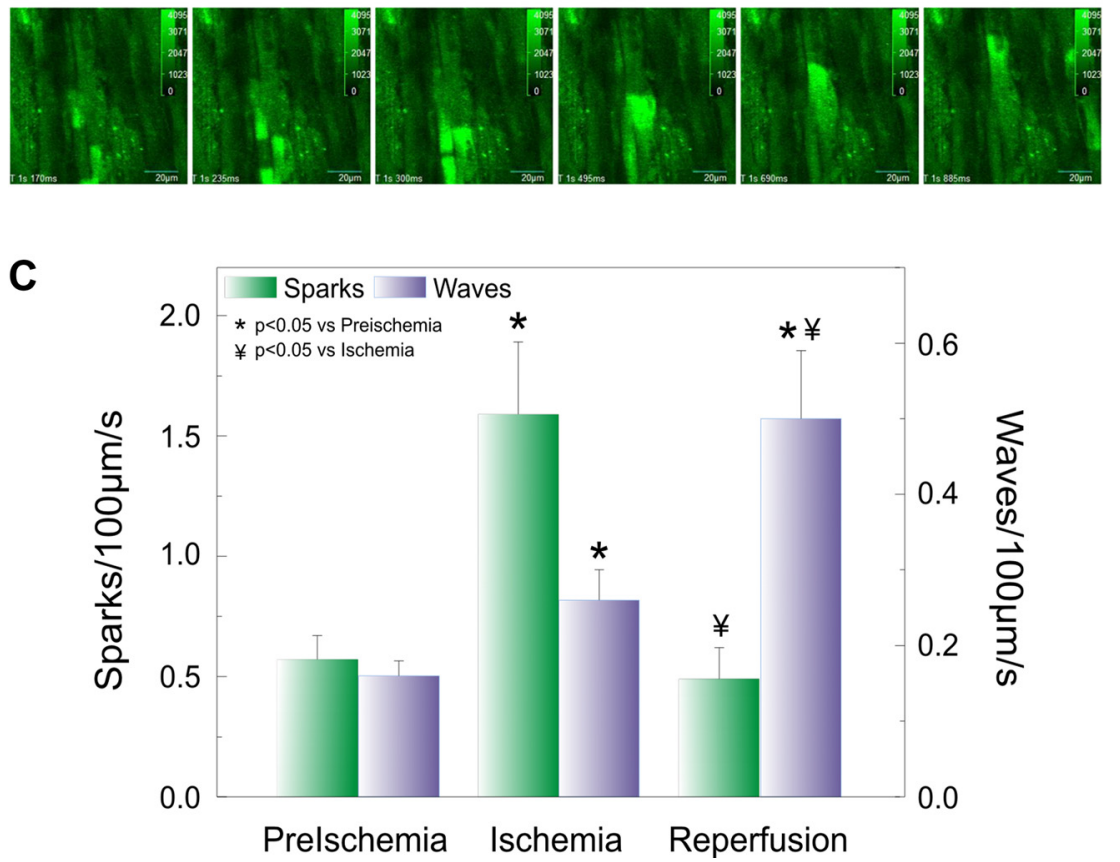
Dual role of CaMKII in $I / R$. In the last few years, a dual effect of CaMKII-dependent protein phosphorylation (beneficial and detrimental) has been described in the scenario of I/R in the intact heart. The beneficial effect of CaMKII refers to the recovery of intracellular $\mathrm{Ca}^{2+}$ and contractile function that occurs during stunning $(109,133)$, a fully reversible postischemic dysfunction (20). It has been shown that phosphorylation of PLN-Thr ${ }^{17}$ is essential for the recovery of $\mathrm{Ca}^{2+}$ transients and contractility in the stunned heart $(109,133)$, offering a mechanism that helps to limit cytosolic $\mathrm{Ca}^{2+}$ overload, by accelerating SR $\mathrm{Ca}^{2+}$ reuptake and ameliorating intracellular $\mathrm{Ca}^{2+}$ handling.

The detrimental effect of CaMKII refers to the role of CaMKII in reperfusion arrhythmias, which occur even after a short ischemic period $(11,108)$, and to the necrosis and apoptosis typical of the irreversible I/R injury $(28,110,140)$. Targeted inhibition of CaMKII at the level of cardiac SRmembranes in mice (SR-AIP) clearly indicated that most of reperfusion arrhythmias are triggered by CaMKII-dependent mechanisms (108). Moreover, prevention of CaMKII-dependent phosphorylation of RyR2 was able to significantly reduce reperfusion arrhythmias (108), but failed to completely prevent them. These findings indicate that other CaMKII targets may be involved in reperfusion arrhythmias. A possible candidate is $\mathrm{Thr}^{17}$ of PLN, which is phosphorylated at the beginning of reperfusion in association with the increase in CaMKII phosphorylation of $\mathrm{Ser}^{2814}$ of RyR2 (108). Phosphorylation of $\mathrm{Thr}^{17}$ and the consequent increase in SR $\mathrm{Ca}^{2+}$ reuptake could produce two opposite effects, which are actually inherent to the characteristics of SR $\mathrm{Ca}^{2+}$ uptake itself. On one hand, increasing SERCA2a activity would increase the rate of resequestration of the $\mathrm{Ca}^{2+}$ released through RyR2. This would reduce cytosolic $\mathrm{Ca}^{2+}$ levels, increasing the availability of free cytosolic buffer sites able to bind $\mathrm{Ca}^{2+}$ (increase in dynamic cytosolic buffer capacity). This may limit $\mathrm{Ca}^{2+}$ wave propagation and reperfusion arrhythmias $(4,53)$. On the other hand, increasing $\mathrm{Ca}^{2+}$ sequestration would necessarily increase SR $\mathrm{Ca}^{2+}$ content, favoring diastolic $\mathrm{Ca}^{2+}$ leak. This situation would be exacerbated if the increase in $\mathrm{SR} \mathrm{Ca}^{2+}$ uptake coexists with an increase in the open probability of RyR2, as that produced by CaMKII-dependent phosphorylation (134), and may contribute to favor a futile circle of increased SR $\mathrm{Ca}^{2+}$ uptake and leak with an additional metabolic cost. Thus the beneficial effects of the increase in SR $\mathrm{Ca}^{2+}$ uptake in I/R may turn to be deleterious under conditions in which the balance between SR $\mathrm{Ca}^{2+}$ uptake and leak is lost. Finally, although in the experiments in SR-AIP mice with inhibition of CaMKII targeted to the SR, reperfusion arrhythmias virtually disappeared, phosphorylation of LTCC by CaMKII was also inhibited in these mice (98). Thus the contribution of CaMKIIdependent LTCC phosphorylation to reperfusion arrhythmias cannot be excluded.

After a prolonged ischemic period, reperfusion evokes irreversible cardiac injury. Under these conditions, myocytes die by apoptosis, autophagy, and necrosis. Experimental evidence indicates that CaMKII inhibition is protective in the irreversible I/R injury $(28,110,140,154)$. Although the mechanisms of this protection are still unclear, it has been established that CaMKII is clearly involved in the intrinsic (mitochondrial) cell death pathway (110). This signaling pathway involves CaMKII-dependent phosphorylation of SR protein(s), mitochon- drial $\mathrm{Ca}^{2+}$ overload, cytochrome $c$ release, and caspase-3 activation $(28,110,140)$. Notably, this cascade of events mediates not only the programmed cell death known as apoptosis but also a CaMKII-dependent programmed necrosis (110). These deleterious effects appear to be associated with both RyR2 phosphorylation and caspase-mediated degradation of this protein, which in turn would favor an increase in SR $\mathrm{Ca}^{2+}$ leak. Supporting and extending the signaling cascade described, Joiner et al. (57) showed that CaMKII-dependent phosphorylation of MCU increases $\mathrm{Ca}^{2+}$ entry through it and favors cell death.

Phosphorylation of $\mathrm{Thr}^{17}$, the CaMKII site of PLN, was also transiently enhanced at the onset of reperfusion $(110,140)$. However, the functional consequences of PLN phosphorylation and of the increase in SR $\mathrm{Ca}^{2+}$ uptake after prolonged ischemia are controversial and remain uncertain $(90,126,127$, 151). As discussed for reperfusion arrhythmias, the inconsistent results may reflect the opposite effects of accelerating SR $\mathrm{Ca}^{2+}$ reuptake, which diminishes the diastolic $\left[\mathrm{Ca}^{2+}\right]_{\mathrm{i}}$ elevation produced by increased SR $\mathrm{Ca}^{2+}$ leak, but simultaneously increases SR $\mathrm{Ca}^{2+}$ load, favoring SR $\mathrm{Ca}^{2+}$ leak.

Recent experiments by Di Carlo et al. (28) addressed this puzzle by using mice expressing nonphosphorylatable PLN (i.e., $\mathrm{Ser}^{16}$ and $\mathrm{Thr}^{17}$ mutated to Ala), submitted to I/R. In these mice, cardiac damage was significantly enhanced, suggesting that increasing $\mathrm{Thr}^{17}$ phosphorylation to the level observed at the onset of reperfusion (when phosphorylation of $\mathrm{Ser}^{16} \mathrm{did}$ not occur) has protective effects. However, when CaMKII-dependent RyR2 phosphorylation was selectively precluded, prevention of PLN phosphorylation failed to increase cardiac injury. Thus the results from Di Carlo et al. (28) strongly suggest that CaMKII-dependent inhibition of RyR2 phosphorylation is necessary and sufficient to prevent CaMKII-dependent cardiac damage that originates at the SR level in I/R. Taken together, these findings indicate that the progression toward a beneficial or detrimental effect of CaMKII activation and PLN phosphorylation in I/R would critically depend on the balance between the extent of $\mathrm{SR} \mathrm{Ca}^{2+}$ reuptake and the $\mathrm{SR} \mathrm{Ca}^{2+}$ leak, largely given by the status/characteristics of other proteins also involved in $\mathrm{SR} \mathrm{Ca}^{2+}$ handling, such as RyR2.

\section{CaMKII, Ryanodine Receptors, and Arrhythmias}

CaMKII has been shown to contribute to arrhythmogenesis in cardiac pathologies of different etiology. Although CaMKIIdependent arrhythmogenesis was originally attributed to its impact on sarcolemmal LTCC and the development of early afterdepolarizations, which may indeed occur (1), intense ongoing investigation has provided evidence of multiple additional targets through which CaMKII may exert its arrhythmogenic action. Among these, RyR2 seem to be one of particular functional importance. A CaMKII-dependent increase in RyR2 open probability has been shown to increase $\mathrm{SR} \mathrm{Ca}^{2+}$ leak, which would enhance $\mathrm{Ca}^{2+}$ extrusion via the electrogenic NCX. This electrogenic transport generates a depolarizing current $\left(I_{\mathrm{ti}}\right.$ or transient inward current) $(34,114)$, which, when sufficiently large, leads to delayed afterdepolarizations (DADs), that may reach the threshold and trigger spontaneous AP, resulting in extra-systoles and ventricular arrhythmias (146) (Fig. 5). Indeed, extensive experimental evidence demonstrates that CaMKII-induced SR $\mathrm{Ca}^{2+}$ leak is associated 
Fig. 5. Scheme of the possible mechanisms of CaMKIIdependent arrhythmias. Increases in $\left[\mathrm{Ca}^{2+}\right]_{i}$ and/or reactive oxygen species (ROS) can activate CaMKII, which in turn result in further increase in ROS, leading to the phosphorylation and oxidation of the RyR2 and phosphorylation of phospholamban, which, in concert, would enhance SR $\mathrm{Ca}^{2+}$ load and favor SR $\mathrm{Ca}^{2+}$ leak, resulting in an NCX-dependent depolarizing current (transient inward current, or $I_{\mathrm{ti}}$ ), which generates arrhythmogenic delayed afterdepolarization (DADs).

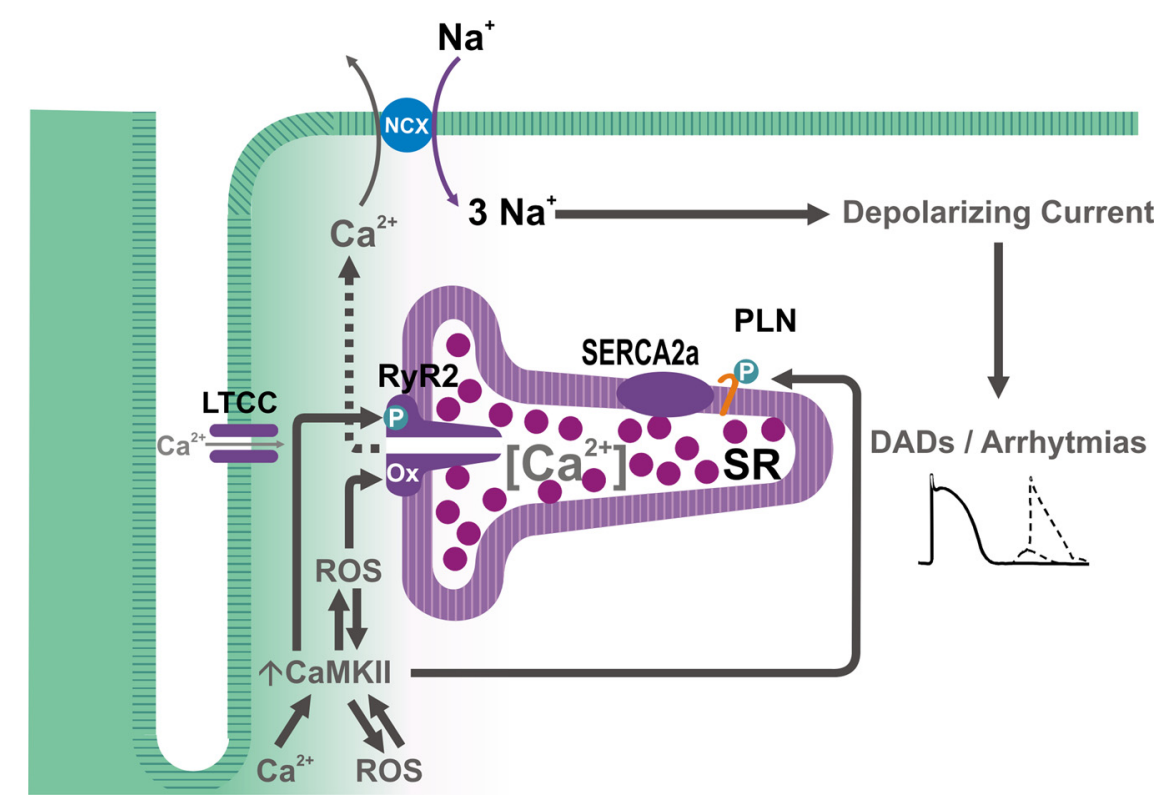

with cardiac arrhythmias. Elegant studies from Wehrens' laboratory showed that genetic inhibition of CaMKII-dependent RyR2 phosphorylation could prevent atrial fibrillation and lethal ventricular arrhythmias $(25,76)$. In addition, several studies have suggested that CaMKII-dependent SR $\mathrm{Ca}^{2+}$ leak also mediates reperfusion arrhythmias, as already discussed in the context of I/R $(13,108)$, heart failure-induced arrhythmias (106), digitalis-induced arrhythmias $(43,50)$, and even arrhythmias of genetic origin, such as catecholaminergic polymorphic tachycardia (69) and those associated with Duchenne muscular dystrophy (2).

Mechanisms underlying CaMKII-dependent regulation of $S R \mathrm{Ca}^{2+}$ leak. The magnitude of SR $\mathrm{Ca}^{2+}$ leak depends on two main factors: 1) SR $\mathrm{Ca}^{2+}$ load and 2) RyR2 open probability. CaMKII can modulate SR $\mathrm{Ca}^{2+}$ load through the phosphorylation of PLN at site $\mathrm{Thr}^{17}$, which relieves the inhibition of PLN on SERCA2a and increases SR $\mathrm{Ca}^{2+}$ uptake (58). CaMKII can also phosphorylate the RyR2 and activate the channel. Indeed, CaMKII was originally shown to phosphorylate the $\mathrm{Ca}^{2+}$ release channel at the site $\operatorname{Ser}^{2809}$ (148), and more recent studies revealed another phosphorylation site at $\operatorname{Ser}^{2814}$ (40, 145). Although the impact of CaMKII phosphorylation on RyR2 function is still a matter of debate, the general consensus indicates that CaMKII increases RyR2 open probability. Whether an independent increase in SR $\mathrm{Ca}^{2+}$ load or in RyR2 open probability is able to produce sufficient $\mathrm{SR} \mathrm{Ca}^{2+}$ leak to induce arrhythmogenic diastolic $\mathrm{Ca}^{2+}$ release, is controversial. $\mathrm{Ca}^{2+}$ overload of the SR has been reported to trigger spontaneous $\mathrm{Ca}^{2+}$ release, at least in part, via the activation of the RyR2 luminal $\mathrm{Ca}^{2+}$ sensor (26). However, several lines of evidence suggest that increased SR $\mathrm{Ca}^{2+}$ load by itself, is not sufficient to promote arrhythmogenic SR $\mathrm{Ca}^{2+}$ release. For example, PLN knock-out mice, which have a fully loaded SR, have not proven to be prone to arrhythmias under basal conditions $(111,155)$. In addition, Venetucci et al. (138) showed that increasing RyR2 open probability alone does not produce arrhythmogenic diastolic $\mathrm{Ca}^{2+}$ release because of the intrinsically accompanying decrease of SR $\mathrm{Ca}^{2+}$ content. Thus, although CaMKII-dependent RyR2 phosphorylation may sen- sitize the RyR2, at basal conditions this can be roughly offset by the lower SR $\mathrm{Ca}^{2+}$ content. However, when SR $\mathrm{Ca}^{2+}$ content is driven up (e.g., by heart rate, sympathetic activation, or post-ischemic $\mathrm{Ca}^{2+}$ overload), the propensity for triggering $\mathrm{SR} \mathrm{Ca}^{2+}$ sparks and waves leading to DADs and arrhythmias can be dramatically increased.

In addition to phosphorylation, RyR2 function may be enhanced by oxidation at the level of specific methionine residues $(16,130)$. RyR2 contains multiple thiols (150) that can be affected by redox modification. RyR 2 thiol oxidation increases the sensitivity of the channel to luminal $\mathrm{Ca}^{2+}$, thus lowering the critical SR $\mathrm{Ca}^{2+}$ content at which spontaneous $\mathrm{Ca}^{2+}$ release occurs (130). As mentioned above, CaMKII can also be activated by oxidation. In addition, recent data suggests that CaMKII can enhance ROS production (116). Thus CaMKII may promote arrhythmogenic RyR2 $\mathrm{Ca}^{2+}$ leak not only by enhancing RyR2 phosphorylation but also by promoting its oxidation. Consistent with this, Ho et al. (51) showed that arrhythmogenic adverse effects of cardiac glycosides involve alterations in RyR2 function caused by oxidative changes in the channel structure. More recently, Gonano and Vila Petroff (42) demonstrated that cardiac glycoside-induced arrhythmias require CaMKII activation, suggesting that CaMKII-dependent RyR2 oxidation could also participate in the development of the arrhythmogenic substrate. Although the relevance of CaMKIIdependent oxidation of RyR2 remains to be further explored, experiments in knock-in mice in which the site $\mathrm{Ser}^{2814}$ of the RyR2 could not be phosphorylated (S2814A mice) provided unequivocal evidence of the importance of phosphorylation of this site in cardiac glycoside-induced arrhythmias (50). Myocytes isolated from S2814A mice did not show enhanced SR $\mathrm{Ca}^{2+}$ leak when exposed to digitoxin, compared with myocytes from wild-type mice. These experiments demonstrate that phosphorylation, rather than oxidation of RyR2, is required for the increase in channel spontaneous activity and arrhythmogenesis in the context of digitalis toxicity.

CaMKII has also been shown to be involved in cardiac arrhythmias associated with acidosis. This is important in the clinical setting since substantial changes in $\mathrm{pH}$ may occur in 
disorders of different origin, such as sleep apnea/hypopnea syndrome, diabetic ketoacidosis, or during episodes of myocardial ischemia. Said et al. (107) showed that ectopic activity produced upon returning to normal $\mathrm{pH}$ after acidosis could be prevented by pharmacologic inhibition of CaMKII and did not occur in a transgenic mouse model with the inhibition of CaMKII targeted to the SR. The authors concluded that CaMKII activation during acidosis favors an increase in $\mathrm{SR} \mathrm{Ca}^{2+}$ load by phosphorylation of PLN $\mathrm{Thr}^{17}$, which, on the one hand, is responsible for the mechanical recovery observed with sustained acidosis, but may also increase spontaneous $\mathrm{SR} \mathrm{Ca}^{2+}$ leak and produce arrhythmias during the return to normal $\mathrm{pH}$. This effect was attributed to the increase in the opening probability of RyR2 due to the $\mathrm{pH}$ increase after acidosis and the acidosis-induced increase in SR $\mathrm{Ca}^{2+}$ content, still present at the beginning of post-acidosis period. The return to normal $\mathrm{pH}$ also leads to recovery of the acidosis-induced inhibition of NCX (97), favoring $\mathrm{Ca}^{2+}$ extrusion and $\mathrm{Na}^{+}$gain into the cell, membrane depolarization, and eventually triggered arrhythmias. Together, these results indicate that post-acidosis CaMKIIdependent DADs are triggered by two concurrent factors: 1) acidosis-induced increase in SR $\mathrm{Ca}^{2+}$ content and 2) relief of acidosis-induced inhibition of RyR2 and NCX.

The evidence provided herein demonstrates the critical role played by CaMKII and RyR2 in arrhythmogenesis and suggests the potential therapeutic benefit of CaMKII inhibition for the treatment of arrhythmias. However, the ubiquitous nature of CaMKII and its effects on different protein targets challenge the use of CaMKII inhibitors as a therapeutic tool. Moreover, pharmacological CaMKII inhibition would probably require compounds selective toward cardiac-specific CaMKII isoforms, which are not currently available. In addition, a targetspecific therapy would be desirable, taking into account the existence of multiple targets for CaMKII activity. For example, the phosphorylation of the PLN site $\mathrm{Thr}^{17}$ plays a key role in the $\beta$-adrenergic inotropic response and mediates the recovery of contractility after cardiac acidosis (107).

The demonstration of RyR2 as a crucial player in the development of CaMKII-induced arrhythmias allows us to postulate an alternative therapeutic approach, which involves the concept of RyR2 stabilization. The term "stabilization" refers to the possibility to reduce RyR2 spontaneous diastolic opening without affecting systolic release. Thus compounds that are able to stabilize the RyR2 could be used to prevent arrhythmias without the undesirable effects of global CaMKII inhibition. Indeed, using the multi-channel blocker JTV-519 (K201), which has been shown to stabilize the RyR2, Sacherer et al. (104) showed, in mouse myocytes and in nonfailing human myocardium treated with the cardiac glycoside ouabain, that JTV-519 was able to reduce the ouabain-induced SR $\mathrm{Ca}^{2+}$ leak. Similarly, additional reports showed that alternative RyR2 stabilizers such as VKII86 or tetracaine could reduce DAD-triggered arrhythmias $(137,156)$. Further work is warranted to find the ideal RyR2 stabilizer, which should reduce spontaneous RyR2 openings during diastole without inhibition of the normal $\mathrm{Ca}^{2+}$-induced $\mathrm{Ca}^{2+}$ release that triggers contraction. This is the case for dantrolene (75), although dantrolene is now only used for acute treatment of malignant hyperthermia. Nevertheless, novel RyR2 stabilizers could be a promising approach for the treatment of arrhythmias of different etiology.
CaMKII in cardiac transcriptional regulation. The foregoing discussion has focused on acute modulatory effects of CaMKII on ion channels, transporters, and myofilaments, but activation of CaMKII can also have major effects on gene transcription. This should be considered as a slower response to certain stress-related signals in which the acute regulatory CaMKII-dependent effects may not be sufficient. This type of transcriptional regulation can be beneficial but can also contribute to maladaptive signals in hypertrophy and HF. Indeed, when myocyte CaMKII is chronically activated, as in all of the above autonomous states (autophosphorylation, oxidation, OGlcNAcylation, nitrosylation), it appears to be largely maladaptive by worsening arrhythmogenic diastolic SR $\mathrm{Ca}^{2+}$ leak and altering expression and gating of ion channels in ways that contribute to arrhythmogenesis. Moreover, this situation seems to occur in HF or upon CaMKII overexpression (either genetically induced or as an intrinsic part of the hypertrophy/HF phenotype). Thus both acute and transcriptional actions of CaMKII can contribute to acute dysfunctions of the type discussed above.

$\mathrm{Ca}^{2+}$-dependent signaling can lead to transcriptional regulation, and we call this process excitation-transcription-coupling (ETC), by analogy to ECC. One ETC pathway that is known to directly involve CaMKII is the CaMKII-dependent phosphorylation of class II histone deacetylases, HDACs, of which HDAC4 and HDAC5 have been the best studied (3, 77, 96, 149). As illustrated in Fig. 6, at baseline when these HDACs are dephosphorylated, they bind to and repress hypertrophic transcription factors, such as myocyte enhancer factor 2 (MEF2). Although these particular HDACs have weak histone deacetylase activity, their presence at MEF2 also prevents histone acetyl transferase localization, resulting in more condensed de-acetylated chromatin structure in this situation. When these HDACs are phosphorylated by CaMKII or protein kinase $\mathrm{D}(\mathrm{PKD})$, translocation out of the nucleus via binding to 14-3-3 chaperone proteins is induced. This translocation relieves MEF2 repression, allows histone acetyl transferase binding, and favors transcriptional activation (Fig. 6). We focus here on the upstream side of these ETC pathways.

Calcineurin $(\mathrm{CaN})$ is an additional $\mathrm{Ca}^{2+}$-dependent ETC pathway that works in parallel with the CaMKII-HDAC pathway (Fig. 6) $(62,81,147)$. When the phosphatase $\mathrm{CaN}$ is activated by $\mathrm{Ca}-\mathrm{CaM}$, it dephosphorylates nuclear factor of activated T cells (NFAT), and dephosphorylated NFAT is translocated to the nucleus where it interacts with transcription factors (e.g., GATA4) and activates the transcription of genes involved in hypertrophic signaling and HF. So, two questions that come up are where $\mathrm{CaN}$ and CaMKII are localized with respect to ETC and whether the same types of $\mathrm{Ca}-\mathrm{CaM}$ signals are likely to drive these two $\mathrm{Ca}-\mathrm{CaM}$-dependent ETC pathways.

Regarding subcellular localization, at baseline in adult ventricular myocytes, both $\mathrm{CaN}$ and CaMKII seem to be preferentially concentrated at the Z-line, at or near the SR T-tubule junctions involved in ECC (but also exist elsewhere). This localization has four important implications. First, if one measures global $\mathrm{CaN}$ or CaMKII activation state, it may be biased by the quantitatively large amount of $\mathrm{CaN}$ and CaMKII at these sites. Second, the local $\left[\mathrm{Ca}^{2+}\right]_{\mathrm{i}}$ in this junctional cleft domain is very different from the global or nuclear $\left[\mathrm{Ca}^{2+}\right]_{\mathrm{i}}$, because of the close proximity to both L-type $\mathrm{Ca}^{2+}$ channels and RyR2 
Fig. 6. $\mathrm{Ca}^{2+}$-dependent signaling in excitation-transcription coupling via $\mathrm{Ca}-\mathrm{CaM}$. CaMKIII can acutely regulate ion channels (that carry $I_{\mathrm{Na}}$ and $I_{\mathrm{Ca}}$ ) and $\mathrm{Ca}^{2+}$ handling proteins (RyR2, $\left.I_{3} R, P L N\right)$, contributing to triggered arrhythmias such as early and delayed afterdepolarization (EADs and DADs). G protein-coupled receptor (GPCR) agonists endothelin-1 (ET-1) and phenylephrine (PE) activate $\mathrm{G} \alpha \mathrm{q} / \beta \gamma$ and phospholipase C (PLC) to produce diacylglycerol (DAG), which can activate protein kinases $\mathrm{C}$ and D. PKC, CaMKII, and PKD can phosphorylate (P) $\mathrm{HDAC}$, and calcineurin $(\mathrm{CaN})$ can dephosphorylate nuclear factor of activated $\mathrm{T}$ cells (NFAT), altering nuclear MEF2- and GATA-dependent transcription.

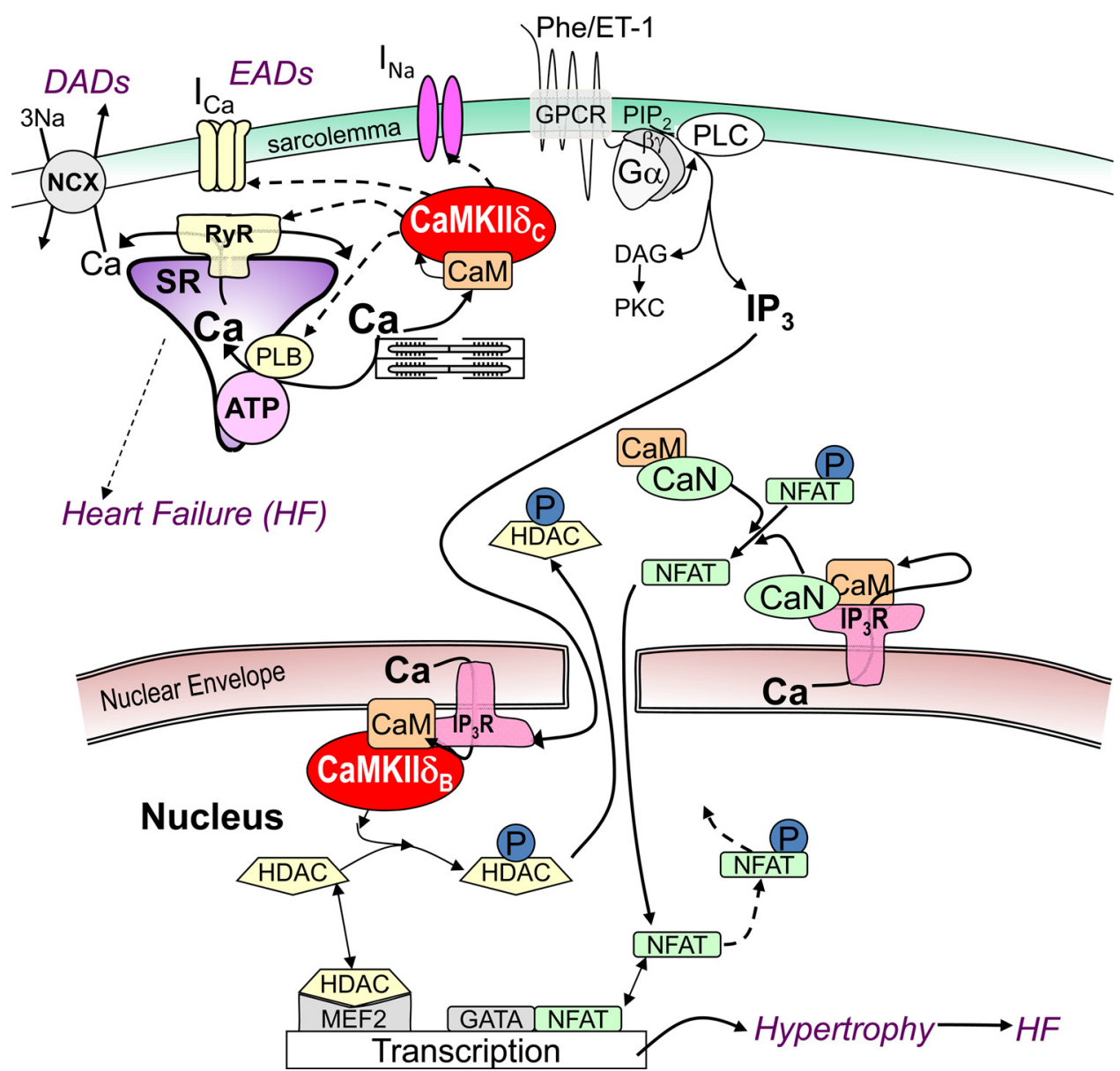

channels (i.e., peak and even diastolic $\left[\mathrm{Ca}^{2+}\right]_{i}$ here can be much higher than anywhere else in the myocyte). Third, there may be significant translocation of $\mathrm{CaN}$ or CaMKII or their downstream targets (e.g., NFAT or HDAC), that could allow $\mathrm{Ca}^{2+}$-dependent signaling in this ECC domain to have longer distance effects on ETC. Fourth, CaN and CaMKII in different subcellular domains (cleft, perinuclear, intranuclear) may have more selective and locally dictated signaling to the ETC machinery. This will be discussed further below.

$\mathrm{CaN}$ and CaMKII have very different $\mathrm{Ca}-\mathrm{CaM}$ affinities, which may be very important functionally. CaMKII has a relatively low Ca-CaM affinity $\left(\mathrm{K}_{\mathrm{d}}=10-50 \mathrm{nM}\right)$, whereas $\mathrm{CaN}$ has a very high Ca-CaM affinity $\left(\mathrm{K}_{\mathrm{d}} \ll 1 \mathrm{nM}\right)(112,113)$. CaMKII activation requires relatively high local $\left[\mathrm{Ca}^{2+}\right]_{i}$ and will tend to de-activate more rapidly when $\left[\mathrm{Ca}^{2+}\right]_{i}$ declines. Thus CaMKII activation works especially well in environments where large local $\mathrm{Ca}^{2+}$ transients occur, such as near the mouths of $\mathrm{Ca}^{2+}$ channels. One place that this occurs is in the ECC cleft near L-type $\mathrm{Ca}^{2+}$ channels and RyR2, and this environment is expected to be more sensitive to CaMKII activation (31). A second location is at the nuclear envelope, where the 1,4,5-inositol-trisphosphate $\left(\mathrm{InsP}_{3}\right)$ receptor (InsP $\mathrm{P}_{3} \mathrm{R}$ ) type 2 (the main isoform in adult ventricular myocytes) is concentrated. Both $\mathrm{CaM}$ and $\mathrm{CaMKII}$ appear to directly associate with the $\mathrm{InsP}_{3} \mathrm{R}(5)$. Thus $\mathrm{Ca}^{2+}$ released by the nuclear envelope $\operatorname{InsP}_{3} \mathrm{R}$ can cause a high local $\left[\mathrm{Ca}^{2+}\right]_{\mathrm{i}}$ that is sufficient to activate CaMKII. That activated nuclear CaMKII can then phosphorylate the $\mathrm{InsP}_{3} \mathrm{R}$ and inhibit channel gating, constituting a local negative feedback loop that may limit the duration of local $\operatorname{InsP}_{3} \mathrm{R} \mathrm{Ca}^{2+}$ release. However, this local CaMKII activation may also be critical for CaMKIIdependent nuclear signaling to HDACs in ETC (149). Note also that CaMKII activation has memory in the form of autonomous activation; that is, if local $\left[\mathrm{Ca}^{2+}\right]_{i}$ is sufficiently high for a long enough time, there is much greater likelihood for a neighboring CaMKII monomer in the dodecameric structure to become autophosphorylated, oxidized, O-GlcNAcylated, or nitrosylated, all of which would prolong the active autonomous state. The other side of this issue is that bulk cytosolic CaMKII (e.g., near PLN or myofilament sites) may not be substantially activated during beat to beat global $\mathrm{Ca}^{2+}$ transients (112). So it is less clear how CaMKII that is not near $\mathrm{Ca}^{2+}$ channels is normally activated.

$\mathrm{CaN}$ activation is very different from that of CaMKII, because of its very high $\mathrm{Ca}-\mathrm{CaM}$ affinity and slow off-rate (112). $\mathrm{CaN}$ that is very near $\mathrm{Ca}^{2+}$ channels that open at each beat (e.g., SR-T-tubule clefts) could be nearly fully activated at each beat, and the slow deactivation could result in nearly fully activated local $\mathrm{CaN}$ at all relevant heart rates. In contrast, cytosolic $\mathrm{CaN}$ that is far away from $\mathrm{Ca}^{2+}$ channels could still be activated in a way that is intrinsically integrating because of the slow off-rate of $\mathrm{Ca}-\mathrm{CaM}$; that is, each $\mathrm{Ca}^{2+}$ transient would slightly increase the CaM-CaN level, but the slow off-rate would mean that it does not relax back before the next $\mathrm{Ca}^{2+}$ pulse drives a bit more $\mathrm{CaM}$ onto $\mathrm{CaN}$. So both $\mathrm{CaN}$ and 
CaMKII exhibit molecular memory, but the molecular basis differs considerably.

Olson's laboratory was the first to demonstrate both the important role of class II HDACs in cardiac ETC, as well as the fact that CaMKII can be an HDAC kinase $(3,96)$. Indeed, both HDAC4 and 5 in cardiac myocytes are phosphorylated by CaMKII and PKD (which is another member of the CaMK kinome family). That HDAC phosphorylation induced HDAC nuclear export, and that could be induced by neurohumoral stimuli [e.g., by endothelin-1 (ET-1) and $\alpha$-adrenergic activation by phenylephrine (PE)], that are known to be parts of the hypertrophic signaling pathway, and also the neurohumoral storm associated with the vicious cycle of HF. The HDAC4 protein contains a specific CaMKII docking, since that CaMKII activation is very tightly linked to HDAC4 nuclear export.

HDAC5 knockout mice exhibit baseline cardiac hypertrophy and have an exaggerated hypertrophic response to pressure overload or cardiac CaN activation (24), suggesting that HDAC5 might be a particularly important ETC pathway in mammalian heart. HDAC5 does not have the CaMKII docking site as in HDAC4, and in HEK cells or cultured neonatal myocytes, HDAC5 nuclear export is controlled by PKD rather than CaMKII. However, in adult ventricular myocytes, where PKD expression is dramatically lower than in the neonate (48), and where CaMKII expression is higher, CaMKII and PKD appear to be equal partners in HDAC5 phosphorylation, nuclear export, and MEF2 driven transcription in response to ET-1 (149). Moreover, ET-1-induced HDAC5 nuclear export was entirely dependent on $\mathrm{Ca}^{2+}$ release through $\mathrm{InsP}_{3} \mathrm{R}$ type 2 at the nuclear envelope, since it was abolished in $\mathrm{InsP}_{3} \mathrm{R} 2$ knockout mice or by $\operatorname{InsP}_{3} \mathrm{R}$ inhibitors, and could be quantitatively mimicked by selective $\operatorname{InsP}_{3} \mathrm{R}$ activation in adult ventricular myocytes (149). HDAC5 translocation driven by the $\alpha$-adrenergic agonist PE is like that induced by ET- 1 at the endothelin receptor in that it is mediated by the G-protein $\mathrm{G}_{\mathrm{aq}}$ (17). Surprisingly, PE-induced HDAC5 nuclear export was completely independent of $\mathrm{Ca}^{2+}, \mathrm{InsP}_{3} \mathrm{R}$, or CaMKII activity and instead was completely dependent on PKC- and PKDdependent signaling (note that PKC did not seem to be important in ET-1-induced HDAC5 nuclear export). Bossuyt et al. (17) used confocal, targeted fluorescence resonance energy transfer (FRET)-based reporters and total internal reflectance fluorescence (TIRF) microscopy to elucidate the mechanism for this ET-1 versus PE difference. For PE activation, PKD was rapidly recruited and activated at the sarcolemma, but then it was very rapidly translocated to the nucleus, where it could phosphorylate HDAC5. For ET-1, PKD was also rapidly recruited to the sarcolemma where it was activated, but in this case, PKD largely remained at the sarcolemma and did not shuttle to the nucleus. So although PKD can powerfully drive HDAC5 nuclear export, it depends on how PKD is activated. For ET-1, which activates CaMKII via an $\mathrm{InsP}_{3}$-dependent nuclear pathway but activates PKD preferentially at the sarcolemma, nuclear HDAC5 is substantially CaMKII dependent.

During stress, there is often co-activation of the $\mathrm{G}_{\mathrm{q}}$-coupled receptors (ET-1 and $\alpha$-adrenergic) with $\beta$-adrenergic receptors $(\beta-\mathrm{AR})$. Chang et al. (23) evaluated this cross-talk in adult ventricular myocytes. $\beta$-AR activation caused an acute PKAdependent HDAC5 nuclear import that was mediated by PKAdependent phosphorylation of HDAC5 at $\mathrm{Ser}^{279}$, between the two PKD/CaMKII sites $\left(\operatorname{Ser}^{259}\right.$ and $\mathrm{Ser}^{498}$ ), which are respon- sible for driving ET-1 and PE-induced HDAC5 nuclear export. This effect could be mimicked by pseudo-phosphorylation of HDAC5 (S279D) and prevented by a nonphosphorylatable S279A mutant HDAC5. Moreover, this $\beta$-AR effect was dominant over the $\mathrm{G}_{\mathrm{q}}$-coupled receptor effect in that the ET-1 or PE-induced nuclear export was blocked in the S279D HDAC5 mutant or after pretreatment of myocytes with isoproterenol or forskolin. However, chronic $\beta$-AR activation (over $24 \mathrm{~h}$ ) allowed the usual ET-1 and PE effects to occur. Thus acute $\beta$-AR activation may suppress genetic reprogramming driven by this HDAC5 system during the acute fight-or-flight response. However, in chronic activation, as in HF, this $\beta$-ARinduced suppression may be overcome, such that the Gqcoupled signaling drives chronic HDAC5 nuclear export and activation of transcription, which reinforce the genetic HF phenotype (18).

In conclusion, CaMKII signaling in ETC is complex, and much additional work will be needed to fully understand the overall integrated $\mathrm{Ca}-\mathrm{CaM}$ dependent signaling, even by just the CaMKII-HDAC and CaN-NFAT pathways discussed here. But these longer term ETC effects, which can change the expression levels of numerous ion channels and transporters as well as modulate their acute functional behavior in ECC, have to be integrated in the long run.

\section{GRANTS}

This work was supported by PIP 0890 (The National Scientific and Technical Research Council) (to A. Mattiazzi), PICT 0588 (Fondo para la Investigación Científica y Tecnológica) (to M. Vila Petroff), and NIH P01HL080101 and NIH R37-HL030077 (to D. Bers).

\section{DISCLOSURES}

No conflicts of interest, financial or otherwise, are declared by the author(s).

\section{AUTHOR CONTRIBUTIONS}

Author contributions: A.M. conception and design of research; A.M., J.P., C.A.V., M.V.P., and D.M.B. prepared figures; A.M., R.A.B., A.L.E., J.P., M.V.P., and D.M.B. drafted manuscript; A.M., R.A.B., C.A.V., M.V.P., and D.M.B. edited and revised manuscript; A.M., R.A.B., A.L.E., J.P., M.V.P., and D.M.B. approved final version of manuscript.

\section{REFERENCES}

1. Anderson ME. Multiple downstream proarrhythmic targets for calmodulin kinase II: moving beyond an ion channel-centric focus. Cardiovasc Res 73: 657-666, 2007.

2. Ather S, Wang W, Wang Q, Li N, Anderson ME, Wehrens XH. Inhibition of CaMKII phosphorylation of RyR2 prevents inducible ventricular arrhythmias in mice with Duchenne muscular dystrophy. Heart Rhythm 10: 592-599, 2013.

3. Backs J, Olson EN. Control of cardiac growth by histone acetylation/ deacetylation. Circ Res 98: 15-24, 2006.

4. Bai Y, Jones PP, Guo J, Zhong X, Clark RB, Zhou Q, Wang R, Vallmitjana A, Benitez R, Hove-Madsen L, Semeniuk L, Guo A, Song LS, Duff HJ, Chen SR. Phospholamban knockout breaks arrhythmogenic $\mathrm{Ca}^{2+}$ waves and suppresses catecholaminergic polymorphic ventricular tachycardia in mice. Circ Res 113: 517-526, 2013.

5. Bare DJ, Kettlun CS, Liang M, Bers DM, Mignery GA. Cardiac type 2 inositol 1,4,5-trisphosphate receptor: interaction and modulation by calcium/calmodulin-dependent protein kinase II. J Biol Chem 280: 15912-15920, 2005.

6. Bassani JW, Yuan W, Bers DM. Fractional SR Ca release is regulated by trigger $\mathrm{Ca}$ and SR Ca content in cardiac myocytes. Am J Physiol Cell Physiol 268: C1313-C1319, 1995.

7. Bassani RA, Bassani JW. Contribution of $\mathrm{Ca}^{2+}$ transporters to relaxation in intact ventricular myocytes from developing rats. Am J Physiol Heart Circ Physiol 282: H2406-H2413, 2002. 
8. Bassani RA, Bassani JW, Bers DM. Mitochondrial and sarcolemmal $\mathrm{Ca}^{2+}$ transport reduce $\left[\mathrm{Ca}^{2+}\right]_{i}$ during caffeine contractures in rabbit cardiac myocytes. J Physiol 453: 591-608, 1992.

9. Bassani RA, Bers DM. Rate of diastolic Ca release from the sarcoplasmic reticulum of intact rabbit and rat ventricular myocytes. Biophys $J 68$ : 2015-2022, 1995.

10. Bassani RA, Ricardo RA, Bassani JW. Estimation of the fractional sarcoplasmic reticulum $\mathrm{Ca}^{2+}$ release in intact cardiomyocytes using integrated $\mathrm{Ca}^{2+}$ fluxes. Gen Physiol Biophys 31: 401-408, 2012.

11. Bell JR, Curl CL, Ip WT, Delbridge LM. $\mathrm{Ca}^{2+} / \mathrm{calmodulin}^{-d e p e n d e n t ~}$ protein kinase inhibition suppresses post-ischemic arrhythmogenesis and mediates sinus bradycardic recovery in reperfusion. Int J Cardiol 159: 112-118, 2012.

12. Bell JR, Raaijmakers AJ, Curl CL, Reichelt ME, Harding TW, Bei A, Ng DC, Erickson JR, Vila Petroff M, Harrap SB, Delbridge LM. Cardiac CaMKIIdelta splice variants exhibit target signaling specificity and confer sex-selective arrhythmogenic actions in the ischemic-reperfused heart. Int J Cardiol 181C: 288-296, 2014.

13. Bell JR, Vila-Petroff M, Delbridge LM. CaMKII-dependent responses to ischemia and reperfusion challenges in the heart. Front Pharmacol 5: 96, 2014.

14. Bers DM. Cardiac sarcoplasmic reticulum calcium leak: basis and roles in cardiac dysfunction. Апnи Rev Physiol 76: 107-127, 2014.

15. Bolli R, Marban E. Molecular and cellular mechanisms of myocardial stunning. Physiol Rev 79: 609-634, 1999.

16. Boraso A, Williams AJ. Modification of the gating of the cardiac sarcoplasmic reticulum $\mathrm{Ca}^{2+}$-release channel by $\mathrm{H}_{2} \mathrm{O}_{2}$ and dithiothreitol. Am J Physiol Heart Circ Physiol 267: H1010-H1016, 1994.

17. Bossuyt J, Chang CW, Helmstadter K, Kunkel MT, Newton AC, Campbell KS, Martin JL, Bossuyt S, Robia SL, Bers DM. Spatiotemporally distinct protein kinase D activation in adult cardiomyocytes in response to phenylephrine and endothelin. J Biol Chem 286: 3339033400, 2011.

18. Bossuyt J, Helmstadter K, Wu X, Clements-Jewery H, Haworth RS, Avkiran M, Martin JL, Pogwizd SM, Bers DM. $\mathrm{Ca}^{2+} /$ calmodulindependent protein kinase IIdelta and protein kinase D overexpression reinforce the histone deacetylase 5 redistribution in heart failure. Circ Res 102: 695-702, 2008.

19. Boyman L, Chikando AC, Williams GS, Khairallah RJ, Kettlewell S, Ward CW, Smith GL, Kao JP, Lederer WJ. Calcium movement in cardiac mitochondria. Biophys J 107: 1289-1301, 2014.

20. Braunwald E, Kloner RA. The stunned myocardium: prolonged, postischemic ventricular dysfunction. Circulation 66: 1146-1149, 1982.

21. Coultrap SJ, Bayer KU. Nitric oxide induces $\mathrm{Ca}^{2+}$-independent activity of the $\mathrm{Ca}^{2+}$ /calmodulin-dependent protein kinase II (CaMKII). J Biol Chem 289: 19458-19465, 2014.

22. Curran J, Tang L, Roof SR, Velmurugan S, Millard A, Shonts S, Wang H, Santiago D, Ahmad U, Perryman M, Bers DM, Mohler PJ, Ziolo MT, Shannon TR. Nitric oxide-dependent activation of CaMKII increases diastolic sarcoplasmic reticulum calcium release in cardiac myocytes in response to adrenergic stimulation. PLoS One 9: e87495, 2014.

23. Chang CW, Lee L, Yu D, Dao K, Bossuyt J, Bers DM. Acute beta-adrenergic activation triggers nuclear import of histone deacetylase 5 and delays G(q)-induced transcriptional activation. J Biol Chem 288: 192-204, 2013.

24. Chang S, McKinsey TA, Zhang CL, Richardson JA, Hill JA, Olson EN. Histone deacetylases 5 and 9 govern responsiveness of the heart to a subset of stress signals and play redundant roles in heart development. Mol Cell Biol 24: 8467-8476, 2004.

25. Chelu MG, Sarma S, Sood S, Wang S, van Oort RJ, Skapura DG, Li N, Santonastasi M, Muller FU, Schmitz W, Schotten U, Anderson ME, Valderrabano M, Dobrev D, Wehrens XH. Calmodulin kinase II-mediated sarcoplasmic reticulum $\mathrm{Ca}^{2+}$ leak promotes atrial fibrillation in mice. J Clin Invest 119: 1940-1951, 2009.

26. Chen W, Wang R, Chen B, Zhong X, Kong H, Bai Y, Zhou Q, Xie C, Zhang J, Guo A, Tian X, Jones PP, O' Mara ML, Liu Y, Mi T, Zhang L, Bolstad J, Semeniuk L, Cheng H, Chen J, Tieleman DP, Gillis AM, Duff HJ, Fill M, Song LS, Chen SR. The ryanodine receptor store-sensing gate controls $\mathrm{Ca}^{2+}$ waves and $\mathrm{Ca}^{2+}$-triggered arrhythmias. Nat Med 20: 184-192, 2014.

27. Delbridge LM, Bassani JW, Bers DM. Steady-state twitch $\mathrm{Ca}^{2+}$ fluxes and cytosolic $\mathrm{Ca}^{2+}$ buffering in rabbit ventricular myocytes. Am J Physiol Cell Physiol 270: C192-C199, 1996.
28. Di Carlo MN, Said M, Ling H, Valverde CA, De Giusti VC, Sommese L, Palomeque J, Aiello EA, Skapura DG, Rinaldi G, Respress JL, Brown JH, Wehrens XH, Salas MA, Mattiazzi A. CaMKII-dependent phosphorylation of cardiac ryanodine receptors regulates cell death in cardiac ischemia/reperfusion injury. J Mol Cell Cardiol 74: 274-283, 2014.

29. Dong X, Thomas DD. Time-resolved FRET reveals the structural mechanism of SERCA-PLB regulation. Biochem Biophys Res Commun 449: 196-201, 2014.

30. Donoso P, Sanchez G, Bull R, Hidalgo C. Modulation of cardiac ryanodine receptor activity by ROS and RNS. Front Biosci (Landmark Ed) 16: 553-567, 2011.

31. Dries E, Bito V, Lenaerts I, Antoons G, Sipido KR, Macquaide N. Selective modulation of coupled ryanodine receptors during microdomain activation of calcium/calmodulin-dependent kinase II in the dyadic cleft. Circ Res 113: 1242-1252, 2013.

32. Edman CF, Schulman H. Identification and characterization of delta B-CaM kinase and delta C-CaM kinase from rat heart, two new multifunctional $\mathrm{Ca}^{2+} /$ calmodulin-dependent protein kinase isoforms. Biochim Biophys Acta 1221: 89-101, 1994.

33. Eisner D, Bode E, Venetucci L, Trafford A. Calcium flux balance in the heart. J Mol Cell Cardiol 58: 110-117, 2013.

34. Eisner DA, Kashimura T, Venetucci LA, Trafford AW. From the ryanodine receptor to cardiac arrhythmias. Circ J 73: 1561-1567, 2009.

35. Erickson JR, He BJ, Grumbach IM, Anderson ME. CaMKII in the cardiovascular system: sensing redox states. Physiol Rev 91: 889-915, 2011.

36. Erickson JR, Pereira L, Wang L, Han G, Ferguson A, Dao K, Copeland RJ, Despa F, Hart GW, Ripplinger CM, Bers DM. Diabetic hyperglycaemia activates CaMKII and arrhythmias by O-linked glycosylation. Nature 502: 372-376, 2013.

37. Faber GM, Silva J, Livshitz L, Rudy Y. Kinetic properties of the cardiac L-type $\mathrm{Ca}^{2+}$ channel and its role in myocyte electrophysiology: a theoretical investigation. Biophys $J$ 92: 1522-1543, 2007.

38. Fabiato A. Calcium-induced release of calcium from the cardiac sarcoplasmic reticulum. Am J Physiol Cell Physiol 245: C1-C14, 1983.

39. Ferreiro M, Petrosky AD, Escobar AL. Intracellular $\mathrm{Ca}^{2+}$ release underlies the development of phase 2 in mouse ventricular action potentials. Am J Physiol Heart Circ Physiol 302: H1160-H1172, 2012.

40. Ferrero P, Said M, Sanchez G, Vittone L, Valverde C, Donoso P, Mattiazzi A, Mundina-Weilenmann C. $\mathrm{Ca}^{2+} /$ calmodulin kinase II increases ryanodine binding and $\mathrm{Ca}^{2+}$-induced sarcoplasmic reticulum $\mathrm{Ca}^{2+}$ release kinetics during beta-adrenergic stimulation. J Mol Cell Cardiol 43: 281-291, 2007.

41. Gaertner TR, Kolodziej SJ, Wang D, Kobayashi R, Koomen JM, Stoops JK, Waxham MN. Comparative analyses of the three-dimensional structures and enzymatic properties of alpha, beta, gamma and delta isoforms of $\mathrm{Ca}^{2+}$-calmodulin-dependent protein kinase II. $J$ Biol Chem 279: 12484-12494, 2004.

42. Gonano LA, Vila Petroff M. Subcellular mechanisms underlying digitalis-induced arrhythmias: role of calcium/calmodulin-dependent kinase II (CaMKII) in the transition from an inotropic to an arrhythmogenic effect. Heart Lung Circ 23: 1118-1124, 2014.

43. Gonano LA, Sepulveda M, Rico Y, Kaetzel M, Valverde CA, Dedman J, Mattiazzi A, Vila Petroff M. Calcium-calmodulin kinase II mediates digitalis-induced arrhythmias. Circ Arrhythm Electrophysiol 4: 947-957, 2011.

44. Gray CB, Heller Brown J. CaMKIIdelta subtypes: localization and function. Front Pharmacol 5: 15, 2014.

45. Guo T, Zhang T, Mestril R, Bers DM. $\mathrm{Ca}^{2+} /$ Calmodulin-dependent protein kinase II phosphorylation of ryanodine receptor does affect calcium sparks in mouse ventricular myocytes. Circ Res 99: 398-406, 2006.

46. Gutierrez DA, Fernandez-Tenorio M, Ogrodnik J, Niggli E. NOdependent CaMKII activation during beta-adrenergic stimulation of cardiac muscle. Cardiovasc Res 100: 392-401, 2013.

47. Gyorke S, Terentyev D. Modulation of ryanodine receptor by luminal calcium and accessory proteins in health and cardiac disease. Cardiovasc Res 77: 245-255, 2008.

48. Haworth RS, Goss MW, Rozengurt E, Avkiran M. Expression and activity of protein kinase $\mathrm{D} /$ protein kinase $\mathrm{C}$ mu in myocardium: evidence for alpha1-adrenergic receptor- and protein kinase C-mediated regulation. J Mol Cell Cardiol 32: 1013-1023, 2000. 
49. Hidalgo CG, Chung CS, Saripalli C, Methawasin M, Hutchinson KR, Tsaprailis G, Labeit S, Mattiazzi A, Granzier HL. The multifunctional $\mathrm{Ca}^{2+} /$ calmodulin-dependent protein kinase II delta (CaMKIIdelta) phosphorylates cardiac titin's spring elements. J Mol Cell Cardiol 54: 90-97, 2013.

50. Ho HT, Liu B, Snyder JS, Lou Q, Brundage EA, Velez-Cortes F, Wang H, Ziolo MT, Anderson ME, Sen CK, Wehrens XH, Fedorov VV, Biesiadecki BJ, Hund TJ, Gyorke S. Ryanodine receptor phosphorylation by oxidized CaMKII contributes to the cardiotoxic effects of cardiac glycosides. Cardiovasc Res 101: 165-174, 2014.

51. Ho HT, Stevens SC, Terentyeva R, Carnes CA, Terentyev D, Gyorke S. Arrhythmogenic adverse effects of cardiac glycosides are mediated by redox modification of ryanodine receptors. J Physiol 589: 4697-4708, 2011.

52. Hudmon A, Schulman H. Neuronal $\mathrm{Ca}^{2+} /$ calmodulin-dependent protein kinase II: the role of structure and autoregulation in cellular function. Anпu Rev Biochem 71: 473-510, 2002.

53. Huser J, Bers DM, Blatter LA. Subcellular properties of $\left[\mathrm{Ca}^{2+}\right]_{\mathrm{i}}$ transients in phospholamban-deficient mouse ventricular cells. Am J Physiol Heart Circ Physiol 274: H1800-H1811, 1998.

54. Imahashi K, Kusuoka H, Hashimoto K, Yoshioka J, Yamaguchi H, Nishimura T. Intracellular sodium accumulation during ischemia as the substrate for reperfusion injury. Circ Res 84: 1401-1406, 1999.

55. Inserte J, Barba I, Hernando V, Garcia-Dorado D. Delayed recovery of intracellular acidosis during reperfusion prevents calpain activation and determines protection in postconditioned myocardium. Cardiovasc Res 81: 116-122, 2009.

56. Jian Z, Han H, Zhang T, Puglisi J, Izu LT, Shaw JA, Onofiok E, Erickson JR, Chen YJ, Horvath B, Shimkunas R, Xiao W, Li Y, Pan T, Chan J, Banyasz T, Tardiff JC, Chiamvimonvat N, Bers DM, Lam KS, Chen-Izu Y. Mechanochemotransduction during cardiomyocyte contraction is mediated by localized nitric oxide signaling. Sci Signal 7: ra27, 2014.

57. Joiner ML, Koval OM, Li J, He BJ, Allamargot C, Gao Z, Luczak ED, Hall DD, Fink BD, Chen B, Yang J, Moore SA, Scholz TD, Strack S, Mohler PJ, Sivitz WI, Song LS, Anderson ME. CaMKII determines mitochondrial stress responses in heart. Nature 491: 269273, 2012.

58. Karczewski P, Kuschel M, Baltas LG, Bartel S, Krause EG. Sitespecific phosphorylation of a phospholamban peptide by cyclic nucleotide- and $\mathrm{Ca}^{2+} /$ calmodulin-dependent protein kinases of cardiac sarcoplasmic reticulum. Basic Res Cardiol 92, Suppl 1: 37-43, 1997.

59. Kornyeyev D, Petrosky AD, Zepeda B, Ferreiro M, Knollmann B, Escobar AL. Calsequestrin 2 deletion shortens the refractoriness of $\mathrm{Ca}^{2+}$ release and reduces rate-dependent $\mathrm{Ca}^{2+}$-alternans in intact mouse hearts. J Mol Cell Cardiol 52: 21-31, 2012.

60. Kornyeyev D, Reyes M, Escobar AL. Luminal $\mathrm{Ca}^{2+}$ content regulates intracellular $\mathrm{Ca}^{2+}$ release in subepicardial myocytes of intact beating mouse hearts: effect of exogenous buffers. Am J Physiol Heart Circ Physiol 298: H2138-H2153, 2010.

61. Kranias EG, Hajjar RJ. Modulation of cardiac contractility by the phospholamban/SERCA2a regulatome. Circ Res 110: 1646-1660, 2012.

62. Kreusser MM, Backs J. Integrated mechanisms of CaMKII-dependent ventricular remodeling. Front Pharmacol 5: 36, 2014.

63. Lai Y, Nairn AC, Gorelick F, Greengard $\mathbf{P} . \mathrm{Ca}^{2+} /$ calmodulin-dependent protein kinase II: identification of autophosphorylation sites responsible for generation of $\mathrm{Ca}^{2+} /$ calmodulin-independence. Proc Natl Acad Sci USA 84: 5710-5714, 1987.

64. Lanner JT, Georgiou DK, Joshi AD, Hamilton SL. Ryanodine receptors: structure, expression, molecular details, and function in calcium release. Cold Spring Harb Perspect Biol 2: a003996, 2010.

65. Laver DR. Luminal $\mathrm{Ca}^{2+}$ activation of cardiac ryanodine receptors by luminal and cytoplasmic domains. Eur Biophys J 39: 19-26, 2009.

66. Li GR, Du XL, Siow YL, OK, Tse HF, Lau CP. Calcium-activated transient outward chloride current and phase 1 repolarization of swine ventricular action potential. Cardiovasc Res 58: 89-98, 2003.

67. Li J, Marionneau C, Zhang R, Shah V, Hell JW, Nerbonne JM, Anderson ME. Calmodulin kinase II inhibition shortens action potential duration by upregulation of $\mathrm{K}^{+}$currents. Circ Res 99: 1092-1099, 2006.

68. Li N, Timofeyev V, Tuteja D, Xu D, Lu L, Zhang Q, Zhang Z, Singapuri A, Albert TR, Rajagopal AV, Bond CT, Periasamy M, Adelman J, Chiamvimonvat $\mathbf{N}$. Ablation of a $\mathrm{Ca}^{2+}$-activated $\mathrm{K}^{+}$ channel (SK2 channel) results in action potential prolongation in atrial myocytes and atrial fibrillation. J Physiol 587: 1087-1100, 2009.
69. Liu N, Ruan Y, Denegri M, Bachetti T, Li Y, Colombi B, Napolitano C, Coetzee WA, Priori SG. Calmodulin kinase II inhibition prevents arrhythmias in RyR2 $\left(\mathrm{R} 4496 \mathrm{C}^{+/-}\right)$mice with catecholaminergic polymorphic ventricular tachycardia. J Mol Cell Cardiol 50: 214-222, 2011.

70. Lu YM, Huang J, Shioda N, Fukunaga K, Shirasaki Y, Li XM, Han F. CaMKIIdeltaB mediates aberrant NCX1 expression and the imbalance of NCX1/SERCA in transverse aortic constriction-induced failing heart. PLoS One 6: e24724, 2011.

71. Luo M, Anderson ME. Mechanisms of altered $\mathrm{Ca}^{2+}$ handling in heart failure. Circ Res 113: 690-708, 2013.

72. Mani SK, Egan EA, Addy BK, Grimm M, Kasiganesan H, Thiyagarajan T, Renaud L, Brown JH, Kern CB, Menick DR. Beta-adrenergic receptor stimulated Nex1 upregulation is mediated via a CaMKII/ AP-1 signaling pathway in adult cardiomyocytes. $J \mathrm{Mol} \mathrm{Cell} \mathrm{Cardiol} \mathrm{48:}$ 342-351, 2010.

73. Marban E, Kitakaze M, Kusuoka H, Porterfield JK, Yue DT, Chacko VP. Intracellular free calcium concentration measured with 19F NMR spectroscopy in intact ferret hearts. Proc Natl Acad Sci USA 84: 6005-6009, 1987.

74. Mattiazzi A, Argenziano M, Aguilar-Sanchez Y, Mazzocchi G, Escobar AL. Ca Sparks and Ca waves are the subcellular events underlying Ca overload during ischemia and reperfusion in perfused intact hearts. $J$ Mol Cell Cardiol 79C: 69-78, 2015.

75. Maxwell JT, Domeier TL, Blatter LA. Dantrolene prevents arrhythmogenic $\mathrm{Ca}^{2+}$ release in heart failure. Am J Physiol Heart Circ Physiol 302: H953-H963, 2012.

76. McCauley MD, Wehrens XH. Ryanodine receptor phosphorylation, calcium/calmodulin-dependent protein kinase II, and life-threatening ventricular arrhythmias. Trends Cardiovasc Med 21: 48-51, 2011.

77. McKinsey TA, Zhang CL, Olson EN. MEF2: a calcium-dependent regulator of cell division, differentiation and death. Trends Biochem Sci 27: 40-47, 2002.

78. Mejia-Alvarez R, Manno C, Villalba-Galea CA, del Valle Fernandez L, Costa RR, Fill M, Gharbi T, Escobar AL. Pulsed local-field fluorescence microscopy: a new approach for measuring cellular signals in the beating heart. Pfliugers Arch 445: 747-758, 2003.

79. Meyer T, Hanson PI, Stryer L, Schulman H. Calmodulin trapping by calcium-calmodulin-dependent protein kinase. Science 256: 1199-1202, 1992.

80. Miyamae M, Camacho SA, Weiner MW, Figueredo VM. Attenuation of postischemic reperfusion injury is related to prevention of $\left[\mathrm{Ca}^{2+}\right] \mathrm{m}$ overload in rat hearts. Am J Physiol Heart Circ Physiol 271: H2145H2153, 1996.

81. Molkentin JD, Lu JR, Antos CL, Markham B, Richardson J, Robbins J, Grant SR, Olson EN. A calcineurin-dependent transcriptional pathway for cardiac hypertrophy. Cell 93: 215-228, 1998.

82. Moss RL, Fitzsimons DP, Ralphe JC. Cardiac MyBP-C regulates the rate and force of contraction in mammalian myocardium. Circ Res 116: 183-192, 2015.

83. Mundina-Weilenmann C, Said M, Vittone L, Ferrero P, Mattiazzi A. Phospholamban phosphorylation in ischemia-reperfused heart. Effect of pacing during ischemia and response to a beta-adrenergic challenge. Mol Cell Biochem 252: 239-246, 2003.

84. Mundina-Weilenmann C, Vittone L, Cingolani HE, Orchard CH. Effects of acidosis on phosphorylation of phospholamban and troponin I in rat cardiac muscle. Am J Physiol Cell Physiol 270: C107-C114, 1996.

85. Murphy E, Perlman M, London RE, Steenbergen C. Amiloride delays the ischemia-induced rise in cytosolic free calcium. Circ Res 68: 1250$1258,1991$.

86. Murphy E, Steenbergen C. Ion transport and energetics during cell death and protection. Physiology (Bethesda) 23: 115-123, 2008.

87. Nakagami H, Takemoto M, Liao JK. NADPH oxidase-derived superoxide anion mediates angiotensin II-induced cardiac hypertrophy. $J$ Mol Cell Cardiol 35: 851-859, 2003.

88. Neely JR, Rovetto MJ, Whitmer JT, Morgan HE. Effects of ischemia on function and metabolism of the isolated working rat heart. Am J Physiol 225: 651-658, 1973.

89. Negretti N, O'Neill SC, Eisner DA. The relative contributions of different intracellular and sarcolemmal systems to relaxation in rat ventricular myocytes. Cardiovasc Res 27: 1826-1830, 1993.

90. Nicolaou P, Rodriguez P, Ren X, Zhou X, Qian J, Sadayappan S, Mitton B, Pathak A, Robbins J, Hajjar RJ, Jones K, Kranias EG. Inducible expression of active protein phosphatase-1 inhibitor-1 en- 
hances basal cardiac function and protects against ischemia/reperfusion injury. Circ Res 104: 1012-1020, 2009.

91. Niggli E, Ullrich ND, Gutierrez D, Kyrychenko S, Polakova E, Shirokova N. Posttranslational modifications of cardiac ryanodine receptors: $\mathrm{Ca}^{2+}$ signaling and EC-coupling. Biochim Biophys Acta 1833: $866-875,2013$

92. Nishio S, Teshima Y, Takahashi N, Thuc LC, Saito S, Fukui A, Kume O, Fukunaga N, Hara M, Nakagawa M, Saikawa T. Activation of CaMKII as a key regulator of reactive oxygen species production in diabetic rat heart. J Mol Cell Cardiol 52: 1103-1111, 2012.

93. Palomeque J, Rueda OV, Sapia L, Valverde CA, Salas M, Petroff MV, Mattiazzi A. Angiotensin II-induced oxidative stress resets the $\mathrm{Ca}^{2+}$ dependence of $\mathrm{Ca}^{2+}$-calmodulin protein kinase II and promotes a death pathway conserved across different species. Circ Res 105: 12041212, 2009.

94. Palomeque J, Sommese L, Blanco P, Velez Rueda JO, Zanuzzi C, Castro C, Dedman JR, Kaetzel M, Portiansky E, Mattiazzi A. Impaired glucose tolerance induces cardiac apoptosis mediated by CaMKII (Abstract). J Mol Cell Cardiol 65: S98, 2013.

95. Park CO, Xiao XH, Allen DG. Changes in intracellular $\mathrm{Na}^{+}$and $\mathrm{pH}$ in rat heart during ischemia: role of $\mathrm{Na}^{+} / \mathrm{H}^{+}$exchanger. Am J Physiol Heart Circ Physiol 276: H1581-H1590, 1999.

96. Passier R, Zeng H, Frey N, Naya FJ, Nicol RL, McKinsey TA, Overbeek P, Richardson JA, Grant SR, Olson EN. CaM kinase signaling induces cardiac hypertrophy and activates the MEF2 transcription factor in vivo. $J$ Clin Invest 105: 1395-1406, 2000.

97. Philipson KD, Bersohn MM, Nishimoto AY. Effects of $\mathrm{pH}$ on $\mathrm{Na}^{+}$ $\mathrm{Ca}^{2+}$ exchange in canine cardiac sarcolemmal vesicles. Circ Res 50: 287-293, 1982

98. Picht E, DeSantiago J, Huke S, Kaetzel MA, Dedman JR, Bers DM. CaMKII inhibition targeted to the sarcoplasmic reticulum inhibits frequency-dependent acceleration of relaxation and $\mathrm{Ca}^{2+}$ current facilitation. J Mol Cell Cardiol 42: 196-205, 2007.

99. Pike MM, Kitakaze M, Marban E. 23Na-NMR measurements of intracellular sodium in intact perfused ferret hearts during ischemia and reperfusion. Am J Physiol Heart Circ Physiol 259: H1767-H1773, 1990.

100. Ramirez MT, Zhao XL, Schulman H, Brown JH. The nuclear deltaB isoform of $\mathrm{Ca}^{2+} /$ calmodulin-dependent protein kinase II regulates atrial natriuretic factor gene expression in ventricular myocytes. $J$ Biol Chem 272: 31203-31208, 1997.

101. Ronkainen JJ, Hanninen SL, Korhonen T, Koivumaki JT, Skoumal R, Rautio S, Ronkainen VP, Tavi P. $\mathrm{Ca}^{2+}$-calmodulin-dependent protein kinase II represses cardiac transcription of the L-type calcium channel alpha(1C)-subunit gene (Cacna1c) by DREAM translocation. $J$ Physiol 589: 2669-2686, 2011.

102. Rostas JA, Dunkley PR. Multiple forms and distribution of calcium/ calmodulin-stimulated protein kinase II in brain. J Neurochem 59: 1191-1202, 1992.

103. Ruiz-Meana M, Garcia-Dorado D, Julia M, Inserte J, Siegmund B, Ladilov Y, Piper M, Tritto FP, Gonzalez MA, Soler-Soler J. Protective effect of HOE642, a selective blocker of $\mathrm{Na}^{+}-\mathrm{H}^{+}$exchange, against the development of rigor contracture in rat ventricular myocytes. Exp Physiol 85: 17-25, 2000.

104. Sacherer M, Sedej S, Wakula P, Wallner M, Vos MA, Kockskamper J, Stiegler P, Sereinigg M, von Lewinski D, Antoons G, Pieske BM, Heinzel FR. JTV519 (K201) reduces sarcoplasmic reticulum $\mathrm{Ca}^{2+}$ leak and improves diastolic function in vitro in murine and human non-failing myocardium. Br J Pharmacol 167: 493-504, 2012.

105. Sadayappan S, Gulick J, Osinska H, Barefield D, Cuello F, Avkiran M, Lasko VM, Lorenz JN, Maillet M, Martin JL, Brown JH, Bers DM, Molkentin JD, James J, Robbins J. A critical function for Ser-282 in cardiac Myosin binding protein-C phosphorylation and cardiac function. Circ Res 109: 141-150, 2011.

106. Sag CM, Wadsack DP, Khabbazzadeh S, Abesser M, Grefe C, Neumann K, Opiela MK, Backs J, Olson EN, Brown JH, Neef S, Maier SK, Maier LS. Calcium/calmodulin-dependent protein kinase II contributes to cardiac arrhythmogenesis in heart failure. Circ Heart Fail 2: 664-675, 2009.

107. Said M, Becerra R, Palomeque J, Rinaldi G, Kaetzel MA, DiazSylvester PL, Copello JA, Dedman JR, Mundina-Weilenmann C, Vittone $\mathbf{L}$, Mattiazzi A. Increased intracellular $\mathrm{Ca}^{2+}$ and $\mathrm{SR} \mathrm{Ca}^{2+}$ load contribute to arrhythmias after acidosis in rat heart. Role of $\mathrm{Ca}^{2+}$ calmodulin-dependent protein kinase II. Am J Physiol Heart Circ Physiol 295: H1669-H1683, 2008.
108. Said M, Becerra R, Valverde CA, Kaetzel MA, Dedman JR, Mundina-Weilenmann C, Wehrens XH, Vittone L, Mattiazzi A. Calciumcalmodulin dependent protein kinase II (CaMKII): a main signal responsible for early reperfusion arrhythmias. J Mol Cell Cardiol 51: 936-944, 2011.

109. Said M, Vittone L, Mundina-Weilenmann C, Ferrero P, Kranias EG, Mattiazzi A. Role of dual-site phospholamban phosphorylation in the stunned heart: insights from phospholamban site-specific mutants. Am J Physiol Heart Circ Physiol 285: H1198-H1205, 2003.

110. Salas MA, Valverde CA, Sanchez G, Said M, Rodriguez JS, Portiansky EL, Kaetzel MA, Dedman JR, Donoso P, Kranias EG, Mattiazzi A. The signalling pathway of CaMKII-mediated apoptosis and necrosis in the ischemia/reperfusion injury. J Mol Cell Cardiol 48: 1298-1306, 2010.

111. Santana LF, Kranias EG, Lederer WJ. Calcium sparks and excitationcontraction coupling in phospholamban-deficient mouse ventricular myocytes. J Physiol 503: 21-29, 1997.

112. Saucerman JJ, Bers DM. Calmodulin binding proteins provide domains of local $\mathrm{Ca}^{2+}$ signaling in cardiac myocytes. J Mol Cell Cardiol 52: 312-316, 2012.

113. Saucerman JJ, Bers DM. Calmodulin mediates differential sensitivity of CaMKII and calcineurin to local $\mathrm{Ca}^{2+}$ in cardiac myocytes. Biophys $J$ 95: 4597-4612, 2008.

114. Schlotthauer K, Bers DM. Sarcoplasmic reticulum $\mathrm{Ca}^{2+}$ release causes myocyte depolarization. Underlying mechanism and threshold for triggered action potentials. Circ Res 87: 774-780, 2000.

115. Schouten VJ, ter Keurs HE. The slow repolarization phase of the action potential in rat heart. $J$ Physiol 360: 13-25, 1985.

116. Sepulveda M, Gonano LA, Back TG, Chen SR, Vila Petroff M. Role of CaMKII and ROS in rapid pacing-induced apoptosis. J Mol Cell Cardiol 63: 135-145, 2013.

117. Shannon TR, Ginsburg KS, Bers DM. Potentiation of fractional sarcoplasmic reticulum calcium release by total and free intra-sarcoplasmic reticulum calcium concentration. Biophys J 78: 334-343, 2000.

118. Shannon TR, Guo T, Bers DM. $\mathrm{Ca}^{2+}$ scraps: local depletions of free $\left[\mathrm{Ca}^{2+}\right]$ in cardiac sarcoplasmic reticulum during contractions leave substantial $\mathrm{Ca}^{2+}$ reserve. Circ Res 93: 40-45, 2003.

119. Shattock MJ, Bers DM. Rat vs. rabbit ventricle: Ca flux and intracellular $\mathrm{Na}$ assessed by ion-selective microelectrodes. Am J Physiol Cell Physiol 256: C813-C822, 1989.

120. Singer HA, Benscoter HA, Schworer CM. Novel $\mathrm{Ca}^{2+} /$ calmodulindependent protein kinase II gamma-subunit variants expressed in vascular smooth muscle, brain, and cardiomyocytes. J Biol Chem 272: 9393 9400, 1997.

121. Sommese L, Blanco P, Velez Rueda JO, Castro C, Dedman JR, Kaetzel M, Mattiazzi A, Palomeque J. $\mathrm{Ca}^{2+}$-calmodulin kinase II (CaMKII)-dependent alterations in heart rhythm in a model of impaired glucose tolerance (Abstract). J Mol Cell Cardiol 65: S4, 2013.

122. Srinivasan M, Edman CF, Schulman H. Alternative splicing introduces a nuclear localization signal that targets multifunctional $\mathrm{CaM}$ kinase to the nucleus. J Cell Biol 126: 839-852, 1994.

123. Steenbergen C, Perlman ME, London RE, Murphy E. Mechanism of preconditioning. Ionic alterations. Circ Res 72: 112-125, 1993.

124. Sun H, Leblanc N, Nattel S. Mechanisms of inactivation of L-type calcium channels in human atrial myocytes. Am J Physiol Heart Circ Physiol 272: H1625-H1635, 1997.

125. Sun J, Picht E, Ginsburg KS, Bers DM, Steenbergen C, Murphy E. Hypercontractile female hearts exhibit increased S-nitrosylation of the L-type $\mathrm{Ca}^{2+}$ channel alpha1 subunit and reduced ischemia/reperfusion injury. Circ Res 98: 403-411, 2006.

126. Talukder MA, Kalyanasundaram A, Zhao X, Zuo L, Bhupathy $\mathbf{P}$, Babu GJ, Cardounel AJ, Periasamy M, Zweier JL. Expression of SERCA isoform with faster $\mathrm{Ca}^{2+}$ transport properties improves postischemic cardiac function and $\mathrm{Ca}^{2+}$ handling and decreases myocardial infarction. Am J Physiol Heart Circ Physiol 293: H2418-H2428, 2007.

127. Talukder MA, Kalyanasundaram A, Zuo L, Velayutham M, Nishijima Y, Periasamy M, Zweier JL. Is reduced SERCA2a expression detrimental or beneficial to postischemic cardiac function and injury? Evidence from heterozygous SERCA2a knockout mice. Am J Physiol Heart Circ Physiol 294: H1426-H1434, 2008.

128. ten Hove M, Jansen MA, Nederhoff MG, Van Echteld CJ. Combined blockade of the $\mathrm{Na}^{+}$channel and the $\mathrm{Na}^{+} / \mathrm{H}^{+}$exchanger virtually prevents ischemic $\mathrm{Na}^{+}$overload in rat hearts. Mol Cell Biochem 297: 101-110, 2007. 
129. Ten Hove M, Nederhoff MG, Van Echteld CJ. Relative contributions of $\mathrm{Na}^{+} / \mathrm{H}^{+}$exchange and $\mathrm{Na}^{+} / \mathrm{HCO}_{3}{ }^{-}$cotransport to ischemic $\mathrm{Nai}^{+}$ overload in isolated rat hearts. Am J Physiol Heart Circ Physiol 288: H287-H292, 2005.

130. Terentyev D, Gyorke I, Belevych AE, Terentyeva R, Sridhar A, Nishijima Y, de Blanco EC, Khanna S, Sen CK, Cardounel AJ, Carnes CA, Gyorke S. Redox modification of ryanodine receptors contributes to sarcoplasmic reticulum $\mathrm{Ca}^{2+}$ leak in chronic heart failure. Circ Res 103: 1466-1472, 2008.

131. Terentyev D, Rochira JA, Terentyeva R, Roder K, Koren G, Li W. Sarcoplasmic reticulum $\mathrm{Ca}^{2+}$ release is both necessary and sufficient for SK channel activation in ventricular myocytes. Am J Physiol Heart Circ Physiol 306: H738-H746, 2014.

132. Valverde CA, Kornyeyev D, Ferreiro M, Petrosky AD, Mattiazzi A, Escobar AL. Transient $\mathrm{Ca}^{2+}$ depletion of the sarcoplasmic reticulum at the onset of reperfusion. Cardiovasc Res 85: 671-680, 2010.

133. Valverde CA, Mundina-Weilenmann C, Reyes M, Kranias EG, Escobar AL, Mattiazzi A. Phospholamban phosphorylation sites enhance the recovery of intracellular $\mathrm{Ca}^{2+}$ after perfusion arrest in isolated, perfused mouse heart. Cardiovasc Res 70: 335-345, 2006.

134. van Oort RJ, McCauley MD, Dixit SS, Pereira L, Yang Y, Respress JL, Wang Q, De Almeida AC, Skapura DG, Anderson ME, Bers DM, Wehrens XH. Ryanodine receptor phosphorylation by calcium/calmodulin-dependent protein kinase II promotes life-threatening ventricular arrhythmias in mice with heart failure. Circulation 122: 2669-2679, 2010.

135. Van Petegem F. Ryanodine receptors: structure and function. $J$ Biol Chem 287: 31624-31632, 2012

136. Velez Rueda JO, Palomeque J, Mattiazzi A. Early apoptosis in different models of cardiac hypertrophy induced by high renin-angiotensin system activity involves CaMKII. J Appl Physiol (1985) 112: 2110 2120,2012

137. Venetucci LA, Trafford AW, Diaz ME, O'Neill SC, Eisner DA. Reducing ryanodine receptor open probability as a means to abolish spontaneous $\mathrm{Ca}^{2+}$ release and increase $\mathrm{Ca}^{2+}$ transient amplitude in adult ventricular myocytes. Circ Res 98: 1299-1305, 2006.

138. Venetucci LA, Trafford AW, Eisner DA. Increasing ryanodine receptor open probability alone does not produce arrhythmogenic calcium waves: threshold sarcoplasmic reticulum calcium content is required. Circ Res 100: 105-111, 2007.

139. Vila-Petroff M, Mundina-Weilenmann C, Lezcano N, Snabaitis AK, Huergo MA, Valverde CA, Avkiran M, Mattiazzi A. $\mathrm{Ca}^{2+} /$ calmodulin-dependent protein kinase II contributes to intracellular $\mathrm{pH}$ recovery from acidosis via $\mathrm{Na}^{+} / \mathrm{H}^{+}$exchanger activation. J Mol Cell Cardiol 49: $106-112,2010$

140. Vila-Petroff M, Salas MA, Said M, Valverde CA, Sapia L, Portiansky E, Hajjar RJ, Kranias EG, Mundina-Weilenmann C, Mattiazzi A. CaMKII inhibition protects against necrosis and apoptosis in irreversible ischemia-reperfusion injury. Cardiovasc Res 73: 689-698, 2007.

141. Vittone L, Mundina-Weilenmann C, Said M, Ferrero P, Mattiazzi A. Time course and mechanisms of phosphorylation of phospholamban residues in ischemia-reperfused rat hearts. Dissociation of phospholamban phosphorylation pathways. J Mol Cell Cardiol 34: 39-50, 2002.

142. Wagner S, Dybkova N, Rasenack EC, Jacobshagen C, Fabritz L, Kirchhof P, Maier SK, Zhang T, Hasenfuss G, Brown JH, Bers DM, Maier LS. $\mathrm{Ca}^{2+} /$ calmodulin-dependent protein kinase II regulates cardiac $\mathrm{Na}^{+}$channels. J Clin Invest 116: 3127-3138, 2006.
143. Wagner S, Hacker E, Grandi E, Weber SL, Dybkova N, Sossalla S, Sowa T, Fabritz L, Kirchhof P, Bers DM, Maier LS. Ca/calmodulin kinase II differentially modulates potassium currents. Circ Arrhythm Electrophysiol 2: 285-294, 2009.

144. Wehrens XH, Lehnart SE, Marks AR. Intracellular calcium release and cardiac disease. Апnи Rev Physiol 67: 69-98, 2005.

145. Wehrens XH, Lehnart SE, Reiken SR, Marks AR. $\mathrm{Ca}^{2+} /$ calmodulindependent protein kinase II phosphorylation regulates the cardiac ryanodine receptor. Circ Res 94: e61-e70, 2004.

146. Weiss JN, Nivala M, Garfinkel A, Qu Z. Alternans and arrhythmias: from cell to heart. Circ Res 108: 98-112, 2011.

147. Wilkins BJ, Molkentin JD. Calcium-calcineurin signaling in the regulation of cardiac hypertrophy. Biochem Biophys Res Commun 322: 1178-1191, 2004.

148. Witcher DR, Kovacs RJ, Schulman H, Cefali DC, Jones LR. Unique phosphorylation site on the cardiac ryanodine receptor regulates calcium channel activity. J Biol Chem 266: 11144-11152, 1991.

149. Wu X, Zhang T, Bossuyt J, Li X, McKinsey TA, Dedman JR, Olson EN, Chen J, Brown JH, Bers DM. Local InsP3-dependent perinuclear $\mathrm{Ca}^{2+}$ signaling in cardiac myocyte excitation-transcription coupling. $J$ Clin Invest 116: 675-682, 2006.

150. Xu L, Eu JP, Meissner G, Stamler JS. Activation of the cardiac calcium release channel (ryanodine receptor) by poly-S-nitrosylation. Science 279: 234-237, 1998.

151. Yang Y, Zhu WZ, Joiner ML, Zhang R, Oddis CV, Hou Y, Yang J, Price EE, Gleaves L, Eren M, Ni G, Vaughan DE, Xiao RP, Anderson ME. Calmodulin kinase II inhibition protects against myocardial cell apoptosis in vivo. Am J Physiol Heart Circ Physiol 291: H3065-H3075, 2006.

152. Yuan W, Bers DM. Ca-dependent facilitation of cardiac Ca current is due to Ca-calmodulin-dependent protein kinase. Am J Physiol Heart Circ Physiol 267: H982-H993, 1994.

153. Zhang DM, Chai Y, Erickson JR, Brown JH, Bers DM, Lin YF. Intracellular signalling mechanism responsible for modulation of sarcolemmal ATP-sensitive potassium channels by nitric oxide in ventricular cardiomyocytes. J Physiol 592: 971-990, 2014.

154. Zhang R, Khoo MS, Wu Y, Yang Y, Grueter CE, Ni G, Price EE Jr, Thiel W, Guatimosim S, Song LS, Madu EC, Shah AN, Vishnivetskaya TA, Atkinson JB, Gurevich VV, Salama G, Lederer WJ, Colbran RJ, Anderson ME. Calmodulin kinase II inhibition protects against structural heart disease. Nat Med 11: 409-417, 2005.

155. Zhang T, Guo T, Mishra S, Dalton ND, Kranias EG, Peterson KL, Bers DM, Brown JH. Phospholamban ablation rescues sarcoplasmic reticulum $\mathrm{Ca}^{2+}$ handling but exacerbates cardiac dysfunction in CaMKIIdelta(C) transgenic mice. Circ Res 106: 354-362, 2010.

156. Zhou Q, Xiao J, Jiang D, Wang R, Vembaiyan K, Wang A, Smith CD, Xie C, Chen W, Zhang J, Tian X, Jones PP, Zhong X, Guo A, Chen H, Zhang L, Zhu W, Yang D, Li X, Chen J, Gillis AM, Duff HJ, Cheng H, Feldman AM, Song LS, Fill M, Back TG, Chen SR. Carvedilol and its new analogs suppress arrhythmogenic store overloadinduced $\mathrm{Ca}^{2+}$ release. Nat Med 17: 1003-1009, 2011.

157. Zima AV, Bovo E, Bers DM, Blatter LA. $\mathrm{Ca}^{2+}$ spark-dependent and -independent sarcoplasmic reticulum $\mathrm{Ca}^{2+}$ leak in normal and failing rabbit ventricular myocytes. J Physiol 588: 4743-4757, 2010.

158. Zima AV, Picht E, Bers DM, Blatter LA. Termination of cardiac $\mathrm{Ca}^{2+}$ sparks: role of intra-SR $\left[\mathrm{Ca}^{2+}\right]$, release flux, and intra-SR $\mathrm{Ca}^{2+}$ diffusion. Circ Res 103: e105-e115, 2008. 